\title{
Should Unconventional Monetary Policies Become Conventional?*
}

\author{
Dominic Quint ${ }^{\dagger}$ and Pau Rabanal ${ }^{\ddagger}$
}

February 10, 2017

\begin{abstract}
The large recession that followed the Global Financial Crisis of 2008-09 triggered unprecedented monetary policy easing around the world. Most central banks in advanced economies deployed new instruments to affect credit conditions and to provide liquidity at a large scale after short-term policy rates reached their effective lower bound. In this paper, we study if this new set of tools, commonly labeled as unconventional monetary policies (UMP), should still be used when economic conditions and interest rates normalize. We study the optimality of UMP by using an estimated non-linear DSGE model with a banking sector and long-term private and public debt for the United States. We find that the benefits of using UMP in normal times are substantial, equivalent to 1.45 percent of consumption. However, the benefits from using UMP are shock-dependent and mostly arise when the economy is hit by financial shocks. When more traditional business cycle shocks (such as supply and demand shocks) hit the economy, the benefits of using UMP are negligible or zero.
\end{abstract}

JEL Codes: C32, E32, E52

Keywords: Unconventional Monetary Policy, Banking, Optimal Rules

${ }^{*}$ We thank Olivier Blanchard, Mike Kiley, Lars Svensson, and seminar participants at the IMF for useful comments. This Working Paper should not be reported as representing the views of the IMF or the Deutsche Bundesbank. The views expressed in this Working Paper are those of the author(s) and do not necessarily represent those of the Deutsche Bundesbank or those of the IMF or IMF policy. Working Papers describe research in progress by the author(s) and are published to elicit comments and to further debate.

${ }^{\dagger}$ Deutsche Bundesbank, Wilhelm-Epstein-Strasse 14, 60431 Frankfurt am Main. Email: dominic.quint@bundesbank.de

${ }^{\ddagger}$ Corresponding author. Research Department, International Monetary Fund. 700 19th St NW, Washington, DC 20431. Email: prabanal@imf.org 
"In pre-crisis days, policymakers assumed that tweaking short-term interest rates was enough to influence all important financial decision-making. This was wishful thinking, based on a couple of decades of atypical US experience. Other economies still needed extra policy instruments, as has the US since the crisis."

Adam Posen, Financial Times, August 23, 2016

"The long-term interest rate is a central variable in the macroeconomy. It matters to borrowers looking to start a business or purchase a home; to lenders weighing the risks and rewards of extending credit; to savers preparing for college or retirement; and to policymakers gauging the state of the economy and financing government expenditure."

US Council of Economic Advisers, Report on "Long-Term Interest Rates: A Survey", July 2015

\section{Introduction}

The economic fallout from the Global Financial Crisis 2008-09 triggered unprecedented monetary policy easing around the world. Initially, central banks responded aggressively by decreasing interest rates until reaching their effective lower bound. Afterwards, central banks in most advanced economies started deploying a new set of instruments to provide liquidity and affect credit conditions at a large scale. These interventions, that became commonly known as unconventional monetary policy, were introduced via large scale asset purchase programs of domestic assets (including government bonds, mortgage backed securities, and private sector debt) as well as liquidity provision and refinancing operations with commercial banks. ${ }^{1}$ As a result of such unconventional policies, central bank balance sheets expanded to unprecedented levels. For instance, the Federal Reserve's balance sheet fluctuated at about 6 percent of annual GDP on average between 1955-2007, but it more than quadrupled since then to 25 percent of GDP in 2015. For other major central banks, the same ratio evolved as follows: in the UK, the ratio went from 6.5 percent on average between 1955-2007 to 22.5 percent in 2014. In the Euro Area, the ratio went from 13 percent in 2006, to 30 percent in

\footnotetext{
${ }^{1}$ Lenza et al. (2010) provide an overview on the different actions taken by the Fed, the Bank of England and the ECB in response to the crisis. Gagnon et al. (2011) compare the policy steps taken by the Fed with the ones taken by Bank of Japan and the Bank of England. Fratzscher et al. (2016) study the international spillovers of the main actions taken by the ECB after the crisis.
} 
2012, and back to 22 percent in 2015. In Japan, this ratio went from 10 percent in 1994, to 21 percent right before the crisis in 2007, and to 61 percent in 2014.

During the crisis, and specially after the collapse of Lehman Brothers, corporate lending spreads increased to levels only comparable to the Great Depression, and borrowers saw their access to credit deteriorate (see e.g. Ivashina and Scharfstein, 2010). By adopting unconventional policy instruments, policymakers pursued broadly two goals. First, as shortterm interest rates quickly reached their lower bound, central banks needed to use other tools to provide further monetary policy accommodation to affect spreads between shortterm and long-term rates directly. Second, with the provision of liquidity at a large scale, central banks aimed at restoring the functioning of credit and financial markets, and the transmission mechanism of monetary policy that had become impaired.

In this paper, we study if the unconventional tools deployed during the crisis should become conventional and still be used after the economy and interest rates return to more normal conditions. We focus on whether monetary policy should target both the short-term rate and the spread between long- and short-term rates when the zero lower bound is not binding. In this sense, we will offer guidance on the question whether central banks should aim at phasing out their new measures introduced during the recent crisis or whether there are benefits in adding asset purchase programs to their standard policy toolkit. ${ }^{2}$ Prior to the crisis, the prevailing consensus was that an expansion of the monetary base was regarded as having no effect on real variables (e.g. Wallace, 1981; Eggertsson and Woodford, 2003). Instead, the prevailing view was that central banks should focus on communicating the path of the short-term interest rate (e.g. via a transparent policy function) and allow monetary policy to be transmitted along the yield curve of government bonds as well as across private financial asset classes, including bank loans. This transmission mechanism crucially depends on the assumption of efficient financial markets (in the spirit of Fama, 1970). However, in the presence of market segmentation, the perfect substitutability between different financial assets breaks down, and policy makers can affect yields above and beyond targeting the

\footnotetext{
${ }^{2}$ When the Fed increased rates for the first time in almost a decade at the end of 2015, it indicated that it is going to keep the size of its balance sheet unchanged: "The Committee is maintaining its existing policy of reinvesting principal payments from its holdings of [financial assets] and it anticipates doing so until normalization of the level of the federal funds rate is well under way. This policy, by keeping the Committee's holdings of longer-term securities at sizable levels, should help maintain accommodative financial conditions." This policy has been reiterated in all FOMC statements during 2016, see Federal Reserve System (2016).
} 
short-term interest rate.

One advantage in making these unconventional measures conventional would be that central banks could avoid the well known "Greenspan conundrum" (Greenspan, 2005). Conventional monetary policy affects the short-term rate, but it might not be able to affect long-term rates with the same precision because of time-varying term and risk premia. Longer term rates have stronger macroeconomic effects, as our quote from the US Council of Economic Advisers above suggests (see also Thornton, 2012). On the other hand, unconventional measures might be associated with welfare costs when affecting the slope of the yield curve away from its market-driven equilibrium value. Furthermore, since the history of unconventional policy measures shows diminishing returns (e.g. Krishnamurthy and Vissing-Jorgensen, 2011), unconventional policy might only be effective when the economy is hit by large financial shocks or when conducted at a larger scale than is politically feasible.

To answer these questions, we rely on a general equilibrium model based on Justiniano et al. (2013), which is augmented with a banking sector as in Gertler and Karadi (2013) and Andreasen et al. (2013). In the model, banks channel funds from households to non-financial firms and the government. Banks raise short-term deposits, provide long-term loans to firms and purchase long-term government bonds, thereby facilitating maturity transformation. Long-term private loans result from the assumption that debtors engage in lumpy investment activities and cannot re-negotiate their debt every period. Given this friction, the return on private assets as well as on government papers becomes sticky and agents are forward-looking when negotiating these contracts. Our assumptions relating to long-term debt reflect the fact that the majority of outstanding bonds in the US are fixed rate notes. Only around 2 percent of US Treasuries have a variable coupon and around 90 percent of US corporate bonds are issued as fixed rate bonds.

The model is estimated by taking a second-order approximation to the equilibrium conditions, and by using a Generalized Method of Moments (GMM) procedure to match sixtythree relevant first and second order moments from nine macroeconomic and financial time series. The estimated coefficients are obtained to match the data when the model is simulated up to second order. This is important because it allows to account for precautionary savings motives, and also because we rely on the same second-order approximation to the equilibrium conditions for welfare evaluation purposes. In the model, conventional monetary 
policy affects the short-term deposit rate, while unconventional monetary policy encompasses policies targeting the long-term corporate or government bond spreads over the short-term deposit rate. In our model, we only focus on Large Scale Asset Purchases (or LSAPs), and the central bank can conduct these by purchasing either private or government sector debt. When buying private sector debt, the central bank basically crowds out private intermediation. Since banks are leverage constrained - in contrast to the central bank-such a policy is not neutral in affecting spreads and is especially effective when financial shocks, such as shocks to bank capital, hit the economy. By buying government bonds, policy makers can also affect total demand for private securities. These purchases increase banking sector liquidity and lower yields of government bonds. This leads financial intermediaries to rebalance their portfolio into private securities, thereby reducing corporate spreads and stimulating investment. This is the channel central banks have in mind when engaging in Quantitative Easing $(\mathrm{QE})$ measures by purchasing government bonds.

The main results are as follows. Under an estimated Taylor rule, welfare gains from using Unconventional Monetary Policies (UMP) can be up to 1.45 percent of steady-state consumption. In particular, UMP is mostly useful to react to financial shocks, which tend to affect bank leverage and private sector spreads, thereby affecting investment and employment. UMP does not help much with normal "business cycle" supply and demand shocks. In this category we include TFP and investment-specific technology shocks, mark-up shocks to price and wage settting, preference shocks to consumption and labor supply, and government spending shocks. In terms of the modality of UMP, we find that providing direct credit to firms or purchasing government bonds delivers a very similar result. Similar welfare gains from UMP arise when the central bank runs a strict inflation targeting regime, but these benefits are much lower when the central bank follows an optimized Taylor rule that targets price and wage inflation.

Our paper complements the recent theoretical literature which evaluates the UMP measures implemented by central banks during the Global Financial Crisis. These studies differ mainly in the way the perfect substitutability between different financial assets at different maturities is broken down, and thus, how UMP is transmitted to the real economy. Chen et al. (2012) assume that bonds with different maturities are imperfect substitutes and households are willing to pay a premium on bonds of their preferred maturities. In their model, 
the financial friction is at the household level, with some households having a preference for saving with long-term instruments. The transmission channel of UMP in such a framework is very similar to the one of conventional monetary policy. By purchasing assets with an appropriate maturity and altering the return that households earn on these assets, UMP is transmitted by also affecting the consumption-saving decision of households. Chen et al. (2012) find only weak evidence of this transmission channel and therefore negligible effects of UMP on the real economy in the US. Del Negro et al. (2016) focus on the illiquidity of certain assets classes. They assume that, in a crisis, private assets become illiquid compared to government bonds, which gives rise to a premium between these two asset classes. By buying private assets in exchange for liquid assets, the central bank mitigates this effect and helps to counter the decline of investment funding. Calibrated to match liquidity premia during the crisis, Del Negro et al. (2016) show that shocks to the market liquidity of assets can explain a large share of the recession in the US and that the policy response by the Fed played an important role in attenuating the macroeconomic impact of these shocks.

Another stand of the literature focuses on the role of frictions in the intermediation between savers and borrowers (Gertler and Kiyotaki, 2010; Gertler and Karadi, 2011; Cúrdia and Woodford, 2011). Direct lending by the central bank (or targeted asset purchases) can mitigate disruption in the intermediation of funds and therefore becomes desirable when these frictions are non-trivial. In such a framework, the transmission channels of conventional policy and UMP are very different. While the former targets the return earned by savers, the latter is able to directly target the credit costs of borrowers and therefore their investment decision. Gertler and Karadi (2013) extend the framework by incorporating government bonds as (imperfect) substitutes for private securities. In their model, purchases of government bonds will incentivize investors to rebalance their portfolio into private securities due to the arbitrage relation between the return on private assets and government papers. This is a feature that we also incorporate in our model.

The papers listed above focus on the evaluation of the policies implemented during the Global Financial Crisis when the zero (or effective) lower bound became a binding constraint for monetary policy. Therefore, they offer little guidance on the question regarding whether theses instruments should be added to the standard policy toolkit when conventional monetary policy is also available. Two exceptions are the works by Ellison and Tischbirek (2014) 
and Carlstrom et al. (2016). In particular, Ellison and Tischbirek (2014), who build on a similar framework as Chen et al. (2012), find that central banks should coordinate conventional policy and UMP as follows: the former should respond to inflation while the latter should offset output fluctuations. Carlstrom et al. (2016) focus, as we do, on the role of the banking sector in intermediating funds from households to non-financial firms and emphasize the usefulness of UMP measures to counteract shocks that are rooted in the financial sector. Our paper contributes to this debate by using a micro-founded welfare criterion, in contrast to Ellison and Tischbirek (2014), who use a simple, non-microfounded, loss function. Furthermore, we implement long-term credit contracts and a maturity-transformation motive for banks, and unlike Carlstrom et al. (2016), we estimate our model non-linearly, which allows us to fully account for precautionary motives effects. ${ }^{3}$

The rest of the paper is organized as follows. Section 2 describes the key features of our structural model. Section 3 and 4 presents the econometric methodology we use to estimate the parameters of the model and the model fit. We introduce unconventional monetary policy and explain its transmission into the real economy in section 5. Section 6 describes the welfare maximizing policy, while section 7 draws some concluding remarks.

\section{The Model}

Our framework is based on Justiniano et al. (2013), which is a standard New Keynesian model, with nominal and real rigidities and several shocks. ${ }^{4}$ We modify their framework to include a banking sector as in Gertler and Karadi (2013) and a production sector with lumpy investment as in Andreasen et al. (2013). Banks channel funds from households to non-financial firms and the government. Due to an agency problem between bankers and depositors, banks cannot exclusively rely on external financing, which gives rise to a financial accelerator mechanism. In the production sector, we assume that firms can only infrequently adjust their capital stock and negotiate the refinancing of their investment, as in Sveen and Weinke (2007). As a result, firms issue long-term debt, and the nominal lending rate is constant over the life of the loan. A similar structure applies to government bonds.

\footnotetext{
${ }^{3}$ An early contribution by McGough et al. (2005) examines if the central bank should target long-term rates by using conventional monetary policy only.

${ }^{4}$ See also the contributions by Smets and Wouters $(2003,2007)$.
} 
Therefore, the main difference with respect to Gertler and Karadi (2013) is the presence of long-term debt: in our model, banks facilitate maturity transformation. ${ }^{5}$

The model includes households (consisting of workers and bankers), intermediate goods producers, retailers, final goods producers, capital goods producers, financial intermediaries, the central bank and the fiscal authority. In what follows, we present a summary of the model and only elaborate on the main differences between our model and the framework found in Justiniano et al. (2013). For this reason, we start by describing the problem of intermediate goods producers, capital goods producers and financial intermediaries. Then, we briefly describe the remaining agents in the economy, which are standard in this literature. An online appendix includes all the details of the model and a derivation of all equilibrium conditions. ${ }^{6}$

\subsection{Non-Financial Firms}

There are four types of firms operating in the production sector. First, intermediate goods producers hire labor and purchase capital to produce a homogeneous good. These firms face a Calvo (1983)-type restriction when they upgrade their capital stock, which captures the idea that investment expenditures are lumpy (see Reiter et al., 2013). Second, retailers purchase these homogeneous goods and turn them into differentiated goods. Retailers operate under monopolistic competition and charge a mark-up over their marginal costs, i.e. over the price of the intermediate good. The market power of retailers and the associated mark-up is timevarying. We deviate from Justiniano et al. (2013) and follow the Rotemberg (1982) quadratic cost model to implement sticky retail prices. ${ }^{7}$ We assume that retail prices are partially indexed to a combination of steady-state and lagged inflation. Third, final good producers purchase differentiated goods and turn them into final goods that are used for consumption, investment and government spending. Finally, capital-producing firms purchase final goods

\footnotetext{
${ }^{5}$ Gertler and Karadi (2013) also introduce long-term bonds in their model, but they implement them as perpetuities using a short-cut proposed by Woodford (2001). But the aggregate capital stock is refinanced every period. In our model, only a fraction of the capital stock is refinanced every period, which adds realism and also limits the extent to which unconventional monetary policies affect the real economy.

${ }^{6}$ The appendix is available at www.paurabanal.net/research.html

${ }^{7}$ This is mostly for practical reasons, as we will solve our model using a second-order perturbation methods. Implementing price stickiness à la Calvo (1983) together with time-varying mark-ups does not allow to write the optimal price setting equations recursively. This is not an issue when the model is log-linearized, as in Justiniano et al. (2013).
} 
to invest in capital goods that are sold to intermediate goods producers. Creating capital goods is subject to flow adjustment costs. In what follows, we present the optimization problem of intermediate goods producers and capital goods producers in more details. As the retail and the final good sector are fairly standard, we refer the reader to the online appendix for further details.

\subsubsection{Intermediate Goods Producers}

Following Andreasen et al. (2013), every period only a fraction $\left(1-\theta_{k}\right)$ of intermediate goods producers adjust their capital stock. We denote the capital stock adjusted in the current period with $\bar{K}_{t}$. When adjusting to the new capital stock, intermediate goods producers purchase capital from capital good producers financed by a credit obtained from financial intermediaries. The credit contract has a fixed nominal interest rate $\bar{r}_{t}^{L}$, until intermediate goods producers receive the next Calvo signal, which will allow them to adjust the capital stock, pay off the old loan, and negotiate a new loan. The contract signed between intermediate goods producers and capital goods producers allows the former at the end of the contract period to sell the capital stock to the latter at the original price. In addition, intermediate goods producers need to pay a fee to capital goods producers that is a constant fraction of the value of the installed capital stock, $\omega P_{t}^{K} \bar{K}_{t}$, with $P_{t}^{K}$ being the price of capital. As in Andreasen et al. (2013), one can think of these expenditures as compensation to capital producers for providing support and maintenance on installed capital. This setup implies that physical capital exchanged between intermediate goods producers and capital producing firms is valued based on the price of capital when a contract is signed. This way, good-producing firms do not face uncertainty about the price of capital, and the interaction between intermediate good- and capital-producing firms resembles a leasing relationship.

While capital cannot be adjusted every period, producers can change the labor input $L_{t}^{\mathcal{D}}$ every period. We denote the Cobb-Douglas production function for intermediate goods with $Y_{t}^{M}=A_{t}^{(1-\alpha)} Z_{t}\left(K_{t-1}\right)^{\alpha}\left(L_{t}^{\mathcal{D}}\right)^{(1-\alpha)}$, where production is affected by two productivity shocks: a stationary shock $\left(Z_{t}\right)$ that follows an $\mathrm{AR}(1)$ process in logs, and a non-stationary shock $\left(A_{t}\right)$ that follows an $\mathrm{AR}(1)$ process in logs and first differences. The price at which intermediate goods are sold to retailers is $P_{t}^{M}$. Intermediate goods producers solve the following maximization problem taking into account the infrequent adjustment of the capital 
stock:

$$
\begin{aligned}
\max _{\bar{K}_{t}, L_{t+j \mid t}} E_{t} \sum_{j=1}^{\infty}\left\{\left(\theta_{k}\right)^{j-1} \beta^{j} \frac{\Xi_{t+j}}{\Xi_{t}}\right. & {\left[\frac{P_{t+j}^{M}}{P_{t+j}} Y_{t+j \mid t}^{M}-\bar{r}_{t}^{L}\left(\prod_{i=1}^{j} \frac{P_{t+i}}{P_{t+i-1}}\right)^{-1} \frac{P_{t}^{K}}{P_{t}} \bar{K}_{t}\right.} \\
- & \left.\left.\omega\left(\prod_{i=1}^{j} \frac{P_{t+i}}{P_{t+i-1}}\right)^{-1} \frac{P_{t}^{K}}{P_{t}} \bar{K}_{t}-W_{t+j} L_{t+j}^{\mathcal{D}}\right]\right\}
\end{aligned}
$$

where the time notation $t+j \mid t$ indicates production and labor demand at time $t+j$ given that the capital stock was adjusted at time $t$. We denote the consumption goods price index with $P_{t}$ and real wages with $W_{t}$. Since households own firms, the stochastic discount factor $\beta^{j} \Xi_{t+j} / \Xi_{t}$ is derived from the household Euler equation with $\Xi_{t}$ being the marginal utility of consumption. The optimal investment decision is described by:

$$
E_{t} \sum_{j=1}^{\infty}\left\{\left(\theta_{k}\right)^{j-1} \beta^{j} \frac{\Xi_{t+j}}{\Xi_{t}}\left[\frac{P_{t+j}^{M}}{P_{t+j}} \alpha \frac{Y_{t+j \mid t}^{M}}{\bar{K}_{t}}-\left(\prod_{i=1}^{j} \pi_{t+i}\right)^{-1}\left(\bar{r}_{t}^{L}+\omega\right) \frac{P_{t}^{K}}{P_{t}}\right]\right\}=0
$$

where $\pi_{t} \equiv P_{t} / P_{t-1}$ denotes the price inflation rate. Equation (1) links the expected marginal revenue product of capital with the expected marginal cost of maintaining and financing the capital stock. The loan and the service contract are specified in nominal terms, which implies that intermediate goods producers need to take into account expected cumulative inflation. Since all firms can adjust their labor demand every period and since they take wages as given, every firm will demand the same amount of labor irrespectively of its ability to adjust the capital stock. Firms equalize real wages with the marginal revenue product of labor.

\subsubsection{Capital Goods Producers}

Capital goods producers sell capital to intermediate goods producers, with an agreement to repurchase it at the original price. In addition, they provide a service for the maintenance of the capital stock for which they charge a fee that is proportional to the price of capital $\left(\omega P_{t}^{K}\right)$. The duration of the contract is determined in the intermediate good sector. Capital good producers solve the following maximization problem:

$$
\max E_{t} \sum_{j=0}^{\infty} \beta^{j} \frac{\Xi_{t+j}}{\Xi_{t}}\left(\omega \frac{V_{t+j}}{P_{t+j}}-I_{t+j}\right)
$$


with $I_{t}$ being investment spending and where the value of outstanding contracts $V_{t}$ depends on capital vintages sold in previous periods:

$$
\frac{V_{t}}{P_{t}}=\left(1-\theta_{K}\right) \sum_{j=0}^{\infty}\left(\theta_{K}\right)^{j} \frac{P_{t-j}^{K}}{P_{t}} \bar{K}_{t-j} .
$$

The total demand for capital is given by the demand for new capital and the capital stock from last period:

$$
K_{t}=\left(1-\theta_{K}\right) \bar{K}_{t}+\theta_{K} K_{t-1}
$$

while the law of motion for the aggregate capital stock takes into account adjustment costs $\digamma(\cdot)$ for investment:

$$
K_{t}=(1-\delta) K_{t-1}+\xi_{t}^{I}\left[1-\digamma\left(\frac{I_{t}}{I_{t-1}}\right)\right] I_{t}
$$

where $\xi_{t}^{I}$ is an investment shock which follows an $\mathrm{AR}(1)$ process in logs, and $\digamma(\cdot)$ is an increasing, convex function. The equilibrium conditions are derived in the online appendix consisting of a Tobin's Q relation for net investment, together with the conditions that relate the expected marginal revenues from the maintenance service and the expected marginal cost of providing the capital stock.

\subsection{Financial Intermediaries}

Banks use their net worth $N_{t}$ and household deposits $D_{t}$ to provide credit to intermediate good producers and to purchase government bonds. Deposit accounts are kept at financial intermediaries not owned by the household so that financial intermediaries always manage other people's money. This assumption is needed to motivate the moral hazard problem that we describe below. Each period, a banker stays in office with probability $\theta_{B}$. Thus, the expected professional life of a banker is $\left(1-\theta_{B}\right)^{-1}$, and every period a certain mass of bankers become workers (a similar mass of workers become bankers so this keeps proportions stable).

We extend Gertler and Karadi (2013) by introducing long-term private and public debt. In their framework, bankers who exit the market transfer their final period assets to the 
household, which in turn transfer a fraction of that amount to new bankers as "startup funds". This simple mechanism can be implemented because Gertler and Karadi (2011, 2013) have one-period loans only. With long-term debt, banks hold a loan portfolio of different maturities and hence exiting bankers need to sell this portfolio when they retire. As in Andreasen et al. (2013), we introduce an insurance agency financed by a proportional $\operatorname{tax} \tau_{B}$ on banks' profit. When a banker retires, the role of this agency is to create a new bank with an identical asset and liability structure and effectively guarantee the outstanding contracts of the old bank. This agency therefore ensures the existence of a representative bank and that the wealth of this bank is bounded with an appropriately calibrated tax rate.

\subsubsection{Corporate Long-Term Bonds}

The bank manages the portfolio of loans given to the private sector, which includes all loans

given at a nominal amount $P_{t-j}^{K} \bar{K}_{t-j}$ and which pay a gross interest rate of $\bar{R}_{t-j}^{L}$ for each period $j=0,1, \ldots$. We will define the gross interest rate as $\bar{R}_{t}^{L} \equiv 1+\bar{r}_{t}^{L}$. Aggregate real lending to the private sector $l e n_{t}$, which takes into account that loans mature with probability $\theta_{k}$, can be recursively written as:

$$
\operatorname{len}_{t}=\left(1-\theta_{k}\right) \sum_{j=0}^{\infty}\left(\theta_{k}\right)^{j} \frac{P_{t-j}^{K}}{P_{t}} \bar{K}_{t-j},
$$

and the total real revenues rev $_{t}$ earned on the portfolio are given by:

$$
r e v_{t}=\left(1-\theta_{k}\right) \sum_{j=0}^{\infty}\left(\theta_{k}\right)^{j} R_{t-j}^{L} \frac{P_{t-j}^{K}}{P_{t}} \bar{K}_{t-j} .
$$

We define the average return on the private sector loan portfolio by $R_{t}^{L} \equiv \frac{r e v_{t}}{l e n_{t}}$, which is a weighted average of current and past long-term loan interest rates.

\subsubsection{Long-Term Government Bonds}

We introduce long-term government debt in a similar way than private sector debt. Each period, the government issues new debt $B_{t}^{N}$ with a gross interest rate $\bar{R}_{t}^{G}$. Once the security is issued, it pays the net interest rate $\bar{r}_{t}^{G}=\bar{R}_{t}^{G}-1$ each period. In addition, the principal is paid to the holder with probability $1-\theta_{g}$. This implies that the average duration of the 
government bond is $\left(1-\theta_{g}\right)^{-1}$. The law of motion of government bonds is therefore:

$$
B_{t}=\theta_{g} B_{t-1}+B_{t}^{N}
$$

Without loss of generality, and to keep the same notation as with private sector bonds, let's denote $B_{t}^{N}=\left(1-\theta_{g}\right) \bar{B}_{t}$. This will allow us to re-write the law of motion (8) in a similar way to equation (6). Finally, we can express total revenues $r e v_{t}^{G}$ earned on the portfolio of government bonds in a similar way to equation (7) and define the average return on the

government bond portfolio by $R_{t}^{G} \equiv \frac{r e v_{t}^{G}}{B_{t}}$, which is a weighted average of past long-term government bond interest rates.

\subsubsection{Banking Sector}

The balance sheet of the representative bank is defined by its real assets holdings $\left(l e n_{t}+b_{t}\right)$, where $b_{t}=B_{t} / P_{t}$, which are financed through the real net worth of the bank, $n_{t}=N_{t} / P_{t}$, and real deposits, $d_{t}=D_{t} / P_{t}$, collected from households:

$$
\operatorname{len}_{t}+b_{t}=n_{t}+d_{t}
$$

Net worth (or bank capital) is accumulated over time as the difference between earnings on assets and interest payments to households:

$$
n_{t}=\left(1-\tau_{B}\right)\left[R_{t-1}^{L} \frac{P_{t-1}}{P_{t}} l e n_{t-1}+R_{t-1}^{G} \frac{P_{t-1}}{P_{t}} b_{t-1}-R_{t-1} \frac{P_{t-1}}{P_{t}} d_{t-1}\right] \exp \left(\epsilon_{t}^{n w}\right),
$$

where $R_{t}$ is the short-term nominal deposit rate. As explained above, we interpret $\tau_{B}$ as an insurance premium, which helps keep bank capital bounded. $\epsilon_{t}^{n w}$ is an iid shock to banks' net worth. Bankers maximize their expected terminal wealth, which after they retire is transferred as dividends to the households they belong to. Every period bankers can divert a certain fraction of assets and also transfer them to the household they belong to. When bankers divert funds, the bank will be closed and the remaining assets serve as bankruptcy assets. Due to such an agency problem between banks and depositors, the latter demands that bankers have "skin in the game" requiring from them to hold equity $N_{t}$. Thus, the 
following incentive constraint must be satisfied:

$$
\mathcal{V}_{t} \geq \lambda_{t}\left(\operatorname{len}_{t}+\Delta_{t} b_{t}\right)
$$

where $\mathcal{V}_{t}$ is the expected terminal wealth of the bank (defined by the present value of the expected future net worth), $\lambda_{t}$ is the time-varying fraction of loans that can be diverted, and $\lambda_{t} \Delta_{t}$ is the time-varying fraction of government bonds which bankers can embezzle. If $\Delta_{t}<1$, banks will find it easier to divert corporate bonds than government bonds. As a result, the excess return on government bonds is only a fraction $\Delta_{t}$ of the excess return on private securities. The shares $\lambda_{t}$ and $\Delta_{t}$ follow $\operatorname{AR}(1)$ processes in logs. Following Gertler and Karadi (2013), we describe the optimization in the online appendix. However, we want to highlight a few optimality conditions here. The optimal portfolio choice for bankers leads to:

$$
\left(1-\tau_{B}\right) E_{t} \beta \frac{\Xi_{t+1}}{\Xi_{t}} \Omega_{t+1}\left(R_{t}^{L}-R_{t}\right) \frac{P_{t}}{P_{t+1}}=\lambda_{t} \frac{\Theta_{t}}{1+\Theta_{t}}
$$

where $\Theta_{t}$ is the Lagrange multiplier associated with the participation constraint (10), and $\Omega_{t}$ is the shadow value of a unit of net worth to the banker. With a binding participation constraint, the Lagrange multiplier is positive and the participation constraint implies that $\left(R_{t}^{L}-R_{t}\right)>0$. The size of the spread depends on the tightness of the constraint and the exogenous shock $\lambda_{t}$. Also, the optimizing conditions imply the following imperfect substitutability condition between corporate bonds and government bonds $\left(R_{t}^{G}-R_{t}\right)=\Delta_{t}\left(R_{t}^{L}-R_{t}\right)$. Investor demand return equalization up to a factor $\Delta_{t}$, which in our model it is a shock rather than a constant as in Gertler and Karadi (2013).

\subsection{Households and Wage Setting}

As in Gertler and Karadi (2011), we introduce a continuum of households in the economy and differentiate between two types of household members: workers and bankers. Workers supply labor $L_{t}$ and bring wage income $W_{t} L_{t}$ to the household while bankers manage financial intermediaries and bring profits to the household. All household members perfectly pool their consumption risk, with $C_{t}$ describing non-durable consumption spending. Households can only save in deposits $D_{t}$, which pay the nominal deposit rate $R_{t}$. We introduce (inter- 
nal) habit formation in consumption and assume a utility function, which is separable in consumption and hours worked, and which is hit by intertemporal and intratemporal disturbances. Consumption is determined via a standard Euler equation that depends on real interest rates and the intertemporal preference shock.

Following Erceg et al. (2000), each household is a monopolistic supplier of specialized labor. When bargaining wages, this allows households to charge a mark-up over their marginal cost of supplying labor. The market power of households and the associated mark-up is assumed to be time-varying. For the reasons explained above, we deviate from Justiniano et al. (2013) and do not implement the wage rigidity in the spirit of Calvo (1983), but follow the Rotemberg (1982) quadratic adjustment cost instead. Wages are partially indexed to past inflation and TFP growth. Beyond this, households can further adjust wages but they have to pay quadratic adjustment costs to do so.

\subsection{The Government Problem}

Conventional monetary policy is conducted by the central bank with an interest rate rule that targets CPI inflation, $\pi_{t}$, and real output growth, $Y_{t} / Y_{t-1}$. Let $\pi$ be the inflation target of the central bank, $R$ be the steady-state level of the nominal interest rate, $\exp (\Lambda)$ be the growth rate of GDP along the balanced growth path, and $\epsilon_{m, t}$ be an i.i.d. monetary policy shock. The deposit rate is given by:

$$
\frac{R_{t}}{R}=\left(\frac{R_{t-1}}{R}\right)^{\gamma_{R}}\left(\frac{\pi_{t}}{\pi}\right)^{\gamma_{\Pi}\left(1-\gamma_{R}\right)}\left[\frac{Y_{t} / Y_{t-1}}{\exp (\Lambda)}\right]^{\gamma_{y}\left(1-\gamma_{R}\right)} \exp \left(\epsilon_{m, t}\right) .
$$

The ratio of government spending to $\operatorname{GDP}\left(g_{t}=G_{t} / Y_{t}\right)$ follows an $\operatorname{AR}(2)$ process:

$$
\log \left(g_{t}\right)=\left(1-\rho_{g_{1}}-\rho_{g_{2}}\right) \log (g)+\rho_{g_{1}} \log \left(g_{t-1}\right)+\rho_{g_{2}} \log \left(g_{t-2}\right)+\epsilon_{g, t}
$$

where $\epsilon_{g, t} \sim \mathcal{N}\left(0, \sigma_{g}\right)$ is a shock to government spending. The choice of an $\operatorname{AR}(2)$ process is

empirical, and we discuss the calibration in Section 3.1. We also assume that the supply of government bonds as percent of GDP is exogenous with an $\mathrm{AR}(1)$ process:

$$
\frac{b_{t}}{Y_{t}}=\left(1-\rho_{b}\right) \frac{b}{Y}+\rho_{b} \frac{b_{t-1}}{Y_{t-1}}+\epsilon_{b, t}
$$


where $\epsilon_{b, t} \sim \mathcal{N}\left(0, \sigma_{b}\right)$ is a shock to the supply of government bonds. Implicitly, we assume that given a path for exogenous government spending and the debt/GDP ratio, the government will adjust lump-sum transfers such that the government budget constraint holds.

\section{Model Estimation}

As is standard in the literature, we evaluate welfare by taking a second order approximation of the model's equilibrium conditions and to the household's utility function. Therefore, we need to obtain parameter estimates that ensure that the second order approximation of the model fits the data well. Because we are departing from the assumption of linearization, the standard way of proceeding to estimate DSGE models does not apply, which involves using the solution of the model in state-space form and the Kalman filter to evaluate the likelihood function of the linearized model, as explained in An and Schorfheide (2007). ${ }^{8}$ To ensure a good fit, we estimate the model using a Generalized Method of Moments (GMM) procedure as in Christiano and Eichenbaum (1992), Ruge-Murcia (2007), and Andreasen et al. (2016). We use seven macroeconomic series that were used by Justiniano et al. (2013) on US data: real GDP, real consumption, real investment, hours worked, nominal wage growth, GDP deflator inflation, and the Federal Funds target between 1964:2 and 2009:4. In addition, we include two spreads: the spread between BAA corporate yields and the Federal Funds rate as well as the spread between 10 year bond and the Federal Funds rate.

\subsection{Parameter Estimates}

We estimate the model by taking a second order approximation to the equilibrium conditions and applying a GMM methodology. Let $d a t a_{t}$ denote the nine macroeconomic and financial time series we described above. We estimate the model by matching the first moments, the

\footnotetext{
${ }^{8}$ Likelihood based methods for higher order approximations to the equilibrium conditions include the use of non-linear filters such as the particle filter, but they are computationally intensive (see, for instance, Fernández-Villaverde and Rubio-Ramírez, 2007).
} 
contemporaneous second moments, and the persistence in the data. Hence, denote

$$
M_{t} \equiv\left[\begin{array}{c}
\operatorname{data}_{t} \\
\operatorname{vech}\left(\text { data }_{t} d a t a_{t}^{\prime}\right) \\
\operatorname{diag}\left(\text { data }_{t} \operatorname{data}_{t-1}^{\prime}\right)
\end{array}\right]
$$

where the vech () operator selects the lower triangular elements of a matrix and orders them in a vector, and the $\operatorname{diag}()$ operator selects the diagonal elements of a matrix. The size of the $M_{t}$ vector is $63 \times 1$. Letting $\Theta$ denote the vector of structural parameters that we wish to estimate, the GMM estimator is given by:

$$
\hat{\Theta}_{G M M}=\arg \min \left(\frac{1}{T} \sum_{t=1}^{T} M_{t}-\mathbb{E}[\mathbf{M}(\Theta)]\right)^{\prime} \mathbf{W}\left(\frac{1}{T} \sum_{t=1}^{T} M_{t}-\mathbb{E}[\mathbf{M}(\Theta)]\right)
$$

where $\mathbb{E}\left([\mathbf{M}(\Theta)]\right.$ denotes the model-implied moments that are counterparts to $M_{t}$ when taking a second order approximation to the model conditions. $\mathbf{W}$ is a weighting matrix, which is positive definite. We use a conventional two-step approach. First, we use an identity matrix for $\mathbf{W}$ to obtain an initial estimate of the parameters, that we denote by $\Theta_{0}$. Then, we use the inverse of the variance-covariance matrix of $\left(\frac{1}{T} \sum_{t=1}^{T} M_{t}-\mathbb{E}\left[\mathbf{M}\left(\Theta_{0}\right)\right]\right)$ as the weighting matrix, which is obtained with a Newey-West estimator with 10 lags.

Some parameters are calibrated before estimation (see Table 1) and are excluded from $\Theta$. We calibrate these parameters because they are either poorly identified from the data, or because we use other external sources to calibrate them. The elasticities of substitution are calibrated such that steady-state mark-ups are $10 \%$ in the product and $25 \%$ in the labor market. The capital share of output and the depreciation rate are calibrated according to standard values in the literature. We calibrate the average duration of capital stock upgrades to 12 quarters, following the calibration of Sveen and Weinke (2007). We calibrate the average duration of government to 40 quarters (10 years) because this is our counterpart in the data (the 10 year bond). We obtain the parameters for the government spending shock by fitting an $\mathrm{AR}(2)$ process on the (log) government spending/GDP ratio in US data. The parameters $g, \rho_{g_{1}}, \rho_{g_{2}}$, and $\sigma_{g}$ come from that regression. Finally, we calibrate the government debt/GDP ratio as in Gertler and Karadi (2013), and we normalize steady-state hours to 1 
Table 1: Calibrated Parameters

\begin{tabular}{lll}
\hline$\varepsilon_{L}$ & Elasticity of Substitution between Labor & 5 \\
$\varepsilon_{Y}$ & Elasticity of Substitution between Goods & 10 \\
$\alpha$ & Capital share of output & 0.33 \\
$\delta$ & Depreciation rate & 0.025 \\
$1 /\left(1-\theta_{k}\right)$ & Average duration between capital stock changes & 12 \\
$1 /\left(1-\theta_{g}\right)$ & Average duration of government debt & 40 \\
$g$ & Government spending/output ratio & 0.2 \\
$\rho_{g_{1}}$ & $\operatorname{AR}(1)$ coefficient for $G_{t} / Y_{t}$ ratio & 1.288 \\
$\rho_{g_{2}}$ & AR $(2)$ coefficient for $G_{t} / Y_{t}$ ratio & -0.299 \\
$\sigma_{g}$ & Standard deviation innovation $G_{t} / Y_{t}$ Ratio & $1.07 \%$ \\
$b / Y$ & Debt to GDP ratio & 0.45 \\
$L$ & Steady-state hours & 1 \\
\hline
\end{tabular}

(this is the same normalization as in Justiniano et al., 2013).

Table 2 presents the estimated parameters using GMM. We present the asymptotic standard errors which are computed using the asymptotic expression for the variance-covariance matrix of the parameters under GMM estimation and an optimal weighting matrix:

$$
\sqrt{T}\left(\hat{\Theta}-\Theta_{0}\right) \stackrel{d}{\longrightarrow} N\left(0,\left(\mathbf{D}_{\mathbf{o}}^{\prime}\left(\mathbf{S}_{\mathbf{o}}\right)^{-\mathbf{1}} \mathbf{D}_{\mathbf{o}}\right)^{-\mathbf{1}}\right]
$$

where we evaluate these matrices at the estimated parameter values:

$$
\begin{array}{r}
\mathbf{D}_{\mathbf{o}}=\left.\frac{\partial h\left(M_{t}, \Theta\right)}{\partial \Theta^{\prime}}\right|_{\Theta=\hat{\Theta}_{G M M},}, \\
h\left(M_{t}, \Theta\right)=\frac{1}{T} \sum_{t=1}^{T} M_{t}-\mathbb{E}[\mathbf{M}(\Theta)]
\end{array}
$$

and $\mathbf{W}=\left(\mathbf{S}_{\mathbf{o}}\right)^{-\mathbf{1}}$ is the optimal weighting matrix.

Most parameter estimates are in line with previous papers and contributions. We do not impose any type of prior information on the estimation, but for most parameters we impose non-negativity constraints, and for some parameters we also impose an upper bound (for instance, fractions such as indexation coefficients, and $\mathrm{AR}(1)$ coefficents have to be between $[0,1])$. These restrictions do not appear to be binding, since in all cases except the estimated AR(1) coefficient for the financial shock that affects the tightness of the participation constraint, the estimation procedure finds an interior solution.

Despite the differences in the estimation procedure, the parameter estimates are similar 
Table 2: Estimated Parameters

\begin{tabular}{llcc}
\hline & Parameters & Mean & Standard Dev. \\
\hline$h$ & Habit formation & 0.742 & 0.026 \\
$\varphi$ & Inverse Frisch elasticity & 0.847 & 0.077 \\
$1 / \beta-1$ & Discount (in \%) & 0.241 & 0.025 \\
$\log \left(R^{L}-R\right)$ & Corporate Spread (in \%) & 0.388 & 0.011 \\
$\log \left(R^{G}-R\right)$ & Government Spread (in \%) & 0.144 & 0.006 \\
$\Lambda$ & TFP Growth (in \%) & 0.425 & 0.015 \\
$\eta_{i}$ & Investment Adjustment Costs & 8.43 & 0.85 \\
$\theta_{w}$ & Wage Adjustment Cost & 175.33 & 17.78 \\
$\chi_{w}$ & Wage indexation & 0.707 & 0.041 \\
$\theta_{p}$ & Price Adjustment Cost & 62.76 & 4.61 \\
$\chi_{p}$ & Price indexation & 0.421 & 0.044 \\
$\omega$ & Capital Goods Producer Fees & 0.0248 & 0.0009 \\
$\theta_{b}$ & Probability of banker survival & 0.919 & 0.044 \\
$\phi$ & Steady-state Leverage ratio & 15.96 & 1.35 \\
$\gamma_{\Pi}$ & Taylor rule coefficient: Inflation & 1.255 & 0.071 \\
$\gamma_{R}$ & Interest Rate Smoothing & 0.606 & 0.036 \\
$\gamma_{y}$ & Taylor rule coefficient: Output Growth & 0.12 & 0.007 \\
$\pi$ & Inflation Target & 0.972 & 0.097 \\
\hline
\end{tabular}

to other papers in the literature that use Bayesian methods and a linearized version of the model. The habit formation parameter is estimated at 0.74, while in the inverse Frisch elasticity of labor supply is 0.84 . The implied estimated $\beta$ is 0.9975 . The estimated steadystate values for the corporate and government sector spreads imply that the mean of the financial shock that affects the tightness of the participation constraint for government bonds $\left(\Delta_{t}\right)$ is 0.78 . The growth rate of TFP is about 1.6 percent annual rate, as in Christiano et al. (2014). The parameters related to the behavior of investment adjustment costs, price and wage rigidities, and behavior of the banking sector are also within the range of other modelbased evidence or empirical studies. Interestingly, we find that the steady-state leverage ratio is close to 16 , which is much higher than the calibrated value in Gertler and Karadi (2011), but is also closer to the data for financial institutions before the crisis. The estimates for the Taylor rule are on the lower side, with smaller reactions to inflation deviations (1.25), output growth deviations (0.12) and interest rate smoothing coefficients (0.6) than other studies such as Justiniano et al. (2013) and Smets and Wouters (2007).

Table 3 presents the estimated parameters for all the shock processes. It is difficult to compare these estimates with other papers, because changes in modeling assumptions lead 
Table 3: Estimated Parameters

\begin{tabular}{llcc}
\hline & Parameters & Mean & Standard Dev \\
\hline$\rho_{b}$ & AR(1) Government Debt & 0.833 & 0.098 \\
$\rho_{u}$ & AR(1) Preference & 0.967 & 0.015 \\
$\rho_{I}$ & AR(1) Investment & 0.558 & 0.067 \\
$\rho_{\lambda}$ & AR(1) Lambda & 0.999 & 0.0003 \\
$\rho_{\psi}$ & AR(1) Labor supply & 0.623 & 0.053 \\
$\rho_{Z}$ & AR(1) Transitory TFP & 0.947 & 0.033 \\
$\rho_{A}$ & AR(1) Permanent TFP & 0.289 & 0.029 \\
$\rho_{\varepsilon_{Y}}$ & AR(1) Goods Elasticity & 0.871 & 0.186 \\
$\rho_{\Delta}$ & AR(1) Delta & 0.124 & 0.019 \\
$\sigma_{b}$ & SD Government Debt & 0.673 & 0.088 \\
$\sigma_{u}$ & SD Preference & 0.019 & 0.005 \\
$\sigma_{I}$ & SD Investment & 0.075 & 0.016 \\
$\sigma_{\lambda}$ & SD Lambda & 0.046 & 0.009 \\
$\sigma_{\psi}$ & SD Labor supply & 0.144 & 0.023 \\
$\sigma_{Z}$ & SD Transitory TFP & 0.007 & 0.0005 \\
$\sigma_{A}$ & SD Permanent TFP & 0.005 & 0.0007 \\
$\sigma_{\varepsilon_{Y}}$ & SD Price Markup & 0.034 & 0.009 \\
$\sigma_{\Delta}$ & SD Delta & 0.138 & 0.039 \\
$\sigma_{\varepsilon_{L}}$ & SD Wage Markup & 0.244 & 0.046 \\
$\sigma_{m}$ & SD Monetary & 0.0033 & 0.0003 \\
$\sigma_{n w}$ & SD Net Worth & 0.184 & 0.021 \\
\hline & & &
\end{tabular}

to changes in the parameter estimates of the shocks. It is worth noting that only one shock is extremely persistent, the $\lambda_{t}$ shock included in the participation constraint (10). Also, as in Justiniano et al. (2013), the growth rate of the permanent TFP shock displays low persistence.

\section{Model Fit}

Since the number of moment conditions is greater than the number of estimated parameters, the model is overidentified. In this case, a model specification J-test is given by:

$$
J=T h\left(M_{t}, \Theta\right)^{\prime}\left(S_{o}\right)^{-1} h\left(M_{t}, \Theta\right) \stackrel{d}{\longrightarrow} \chi_{n_{m}-n_{\Theta}}^{2} .
$$

where $n_{m}$ is the number of moments and $n_{\Theta}$ is the number of parameters. The idea is to check whether $h\left(M_{t}, \hat{\Theta}_{G M M}\right)$ is sufficiently close to zero to suggest that the model fits the data well. We find that the null hypothesis that the model is valid cannot be rejected with 
a p-value of $0.71 .^{9}$

In order to better understand how well the model fits the data, we present the means and standard deviations of each variable, all contemporaneous correlations, and the first autocorrelation of each variable in the data and in the model (Tables 4 and 5). ${ }^{10}$ The fit to the mean of the variables is very good. The only exception is the growth rate of investment, which is higher in the model than in the data. At this point, it is worth emphasizing that there are important risk corrections in the model once second order effects are taken into account. For instance, in the non-stochastic steady state the spreads over the Federal Funds rate were estimated to be 0.38 percent (on a quarterly basis) for the corporate sector and 0.14 percent for the government. However, when second order effects are taken into account, the spreads become 0.61 and 0.23 respectively, and closer to the data (0.71 and 0.22$)$. The level of the spread affects the level of investment and the capital stock in the model, as well as consumption. Therefore, if we had estimated the model up to first order and then performed welfare analysis up to second order, our baseline welfare evaluation would not be aligned with the data. There are also risk corrections for the mean of inflation (0.97 in the non-stochastic steady state and 0.91 up to second order) and hours (0 in the steady state, 0.16 percent in the second order approximation), but these are minor.

When it comes to matching second moments, the estimated model explains the standard deviations and autocorrelations fairly well. The model has trouble matching the volatility of the spreads, because both the mean and the standard deviation of the government sector spreads are a fraction $\Delta_{t}$ of the mean and standard deviation of the corporate spreads. The estimated model is not able to overcome this tight relationship between the two variables, even though $\Delta_{t}$ is stochastic, because it is not volatile enough. The model fit to contemporaneous correlations is also very good. In fact, in all thirty-six cases, the estimation procedure gets the bilateral contemporaneous correlation sign right. The model also explains the persistence of variables well. It only fails in overpredicting the persistence of real consumption and nominal wage growth.

\footnotetext{
${ }^{9}$ More specifically, the values for the J-test are as follows: $\mathrm{T}=183$, the value of the objective function at the optimum is $0.108, n_{m}=63$, and $n_{m}=39$.

${ }^{10}$ Recall that the estimation procedure matches $E\left(M_{t}\right), E\left(M_{t} M_{t}^{\prime}\right)$ and $\operatorname{diag}\left[E\left(M_{t} M_{t-1}^{\prime}\right)\right]$. We present means, standard deviations and correlations as it is typically done in assessing the goodness of fit of a model.
} 
Table 4: Model Fit

\begin{tabular}{lcclcc}
\hline Correlation & Data & Model & Correlation & Data & Model \\
\hline (GDP,C) & 0.57 & 0.62 & (INV,H) & 0.03 & 0.02 \\
(GDP, INV) & 0.88 & 0.85 & (INV,BAA-FFR) & 0.05 & 0.01 \\
(GDP, W) & -0.13 & -0.13 & (INV,10Y-FFR) & 0.21 & 0.01 \\
(GDP, INFL) & -0.24 & -0.38 & (W, INFL) & 0.66 & 0.65 \\
(GDP, FFR) & -0.14 & -0.23 & (W,FFR) & 0.46 & 0.52 \\
(GDP, H) & 0.12 & 0.10 & (W,H) & -0.18 & -0.24 \\
(GDP, BAA-FFR) & 0.05 & 0.06 & (W, BAA-FFR) & -0.42 & -0.03 \\
(GDP, 10Y-FFR) & 0.22 & 0.06 & (W,10Y-FFR) & -0.43 & -0.03 \\
(C,INV) & 0.34 & 0.28 & (INFL,FFR) & 0.65 & 0.76 \\
(C,W) & -0.11 & -0.06 & (INFL, H) & -0.38 & -0.31 \\
(C,INFL) & -0.33 & -0.45 & (INFL,BAA-FFR) & -0.49 & -0.07 \\
(C,FFR) & -0.10 & -0.33 & (INFL,10YFFR) & -0.52 & -0.07 \\
(C,H) & 0.20 & 0.13 & (FFR, H) & -0.38 & -0.42 \\
(C, BAA-FFR) & 0.00 & 0.11 & (FFR,BAA-FFR) & -0.49 & -0.24 \\
(C, 10Y-FFR) & 0.17 & 0.11 & (FFR,10YFFR) & -0.52 & -0.24 \\
(INV,W) & -0.05 & -0.13 & (H,BAA-FFR) & -0.33 & -0.26 \\
(INV, INFL) & -0.11 & -0.24 & (H,10Y-FFR) & -0.24 & -0.26 \\
(INV, FFR) & -0.10 & -0.11 & (BAA-FFR, 10Y-FFR) & 0.94 & 0.997 \\
\hline
\end{tabular}

Next, we report the variance decomposition through the lens of the model. In order to facilitate the reading of Table 5 we aggregate the shocks into preference (intertemporal and intratemporal), TFP (temporary and permanent), investment-specific, financial $\left(\lambda_{t}\right.$, $\Delta_{t}$, net worth, and debt supply), market power (prices and wages), government spending and monetary shocks. Both TFP shocks explain around 40 percent of the fluctuations in output growth, consumption growth, and inflation. Financial shocks are also important, because they explain about 15 percent of GDP fluctuations. Their effect is particularly strong in investment, where they explain about 28 percent of fluctuations, and also in hours, explaining about 18 percent. Furthermore, financial shocks explain more than 80 percent of the fluctuations in both spreads (government bonds and corporate bonds). Preference shocks also explain an important share (between one-third and one-half of fluctuations) of most macroeconomic variables, and up to 50 percent of the volatility of hours. Markup, monetary policy and government spending shocks explain small fractions of economic fluctuations.

Up to this section, we have estimated the model with financial frictions but with monetary policy being conducted with a Taylor-type rule. In the following section, we examine the 
Table 5: Shock Decomposition

\begin{tabular}{lccccccc}
\hline Variable & TFP & Inv & Pref & Fin & Mark-ups & Govt & Mon \\
\hline GDP Growth & 40.7 & 9.7 & 19.0 & 15.8 & 2.6 & 3.8 & 8.6 \\
Consumption Growth & 47.9 & 1.6 & 39.4 & 0.9 & 1.6 & 4.5 & 4.1 \\
Investment Growth & 21.2 & 14.5 & 25.2 & 28.4 & 2.0 & 0.6 & 8.0 \\
Wage Growth & 28.7 & 6.8 & 56.9 & 3.2 & 2.2 & 1.1 & 1.2 \\
Inflation & 39.3 & 3.9 & 46.1 & 3.3 & 4.2 & 1.9 & 1.3 \\
Federal Funds Rate & 24.1 & 4.1 & 41.4 & 3.5 & 2.5 & 1.9 & 22.6 \\
Hours & 9.1 & 8.3 & 50.3 & 18.2 & 2.9 & 9.3 & 2.0 \\
Spread BAA-FFR & 2.5 & 0.2 & 1.5 & 85.5 & 0.4 & 0.1 & 9.9 \\
Spread 10Y Bond-FFR & 2.5 & 0.2 & 1.4 & 85.6 & 0.4 & 0.1 & 9.8 \\
\hline
\end{tabular}

benefits of using UMP in normal times, under the estimated Taylor rule and under alternative conventional monetary policy rules.

\section{$5 \quad$ Implementing UMP in the Model}

UMP in our model is implemented via LSAPs and the central bank purchases either private or government sector debt.

\subsection{Purchases of Corporate Bonds}

Similar to Gertler and Karadi (2011) the central bank provides credit directly to firms when purchasing corporate debt. Gertler and Karadi (2011) assume that the public credit policy is to provide a fraction $\Psi_{t}$ of the stock of credit for firms to borrow. Here, we assume that the central bank UMP rule is in terms of the level of credit (which is more consistent with central banks statements which describe actual amounts rather than fractions). Aggregate lending is given by:

$$
\operatorname{len}_{t}=\left(1-\theta_{k}\right) \frac{P_{t}^{K}}{P_{t}} \bar{K}_{t}+\theta_{k} \frac{P_{t-1}}{P_{t}} \operatorname{len}_{t-1}
$$

where $l e n_{t}=l e n_{t}^{p}+l e n_{t}^{c b}$, and where $l e n_{t}^{p}$ stands for commercial bank credit to the private sector and $l e n_{t}^{c b}$ is central bank credit to the private sector. As we discuss in the appendix, when the central bank lends to the private sector, it reduces the banking sector leverage, thus putting downward pressure on corporate sector spreads. 


\subsection{Purchases of Government Bonds}

In this case the central bank buys government bonds and tries to affect the corporate spread by inducing a portfolio reallocation away from government bonds by banks. The law of motion of government bonds is given by:

$$
B_{t}=\left(1-\theta_{g}\right) \bar{B}_{t}+\theta_{g} \frac{P_{t-1}}{P_{t}} B_{t-1}
$$

where $B_{t}=B_{t}^{p}+B_{t}^{c b}$, and where $B_{t}^{p}$ stands for commercial bank credit to the government, and $B_{t}^{c b}$ is central bank purchases of government bonds. When the central bank buys government bonds, it reduces the amount of government debt being financed by the private financial sector. This reduced bond supply leads to higher bond prices, lower yields and spreads of goverment bonds. This will reduce corporate spreads too, through the imperfect asset subtitutability condition, and increase investment, employment and GDP.

\subsection{The Effects of UMP}

To get a sense of what UMP does in the model, in Figure 1 we plot the impulse responses to a UMP shock, when we take central bank purchases as an exogenous process. Figure 1 shows the case when the stock of assets held by the central bank follows an AR(1) or AR(2) process and UMP is conducted by either lending directly to firms or purchasing government bonds. Two results stand out. First, the impact of UMP policies is stronger when the central bank lends directly to firms than when it purchases government bonds, because it directly affects the private sector spreads, which have a stronger macroeconomic impact. This result echoes the findings of Gertler and Karadi (2013), and means that if UMP is to be implemented via purchases of government bonds, it needs to be deployed at a larger scale. Second, comparing the $\mathrm{AR}(1)$ with the $\mathrm{AR}(2)$ process shows that the latter has strong expansionary effects in our model, showing that announcement effects and a commitment to not to unwind UMP policies in the near future are key to a successful implementation.

Under a persistent $\mathrm{AR}(1)$ shock, the stock of assets increases on impact and the central bank starts unwinding UMP already in $t=1$. The effect of these policies is expansionary on impact because of reduced spreads and increased investment, labor demand and GDP. 
Figure 1: Impulse Response to an Exogenous AR(1) or AR(2) UMP Shock
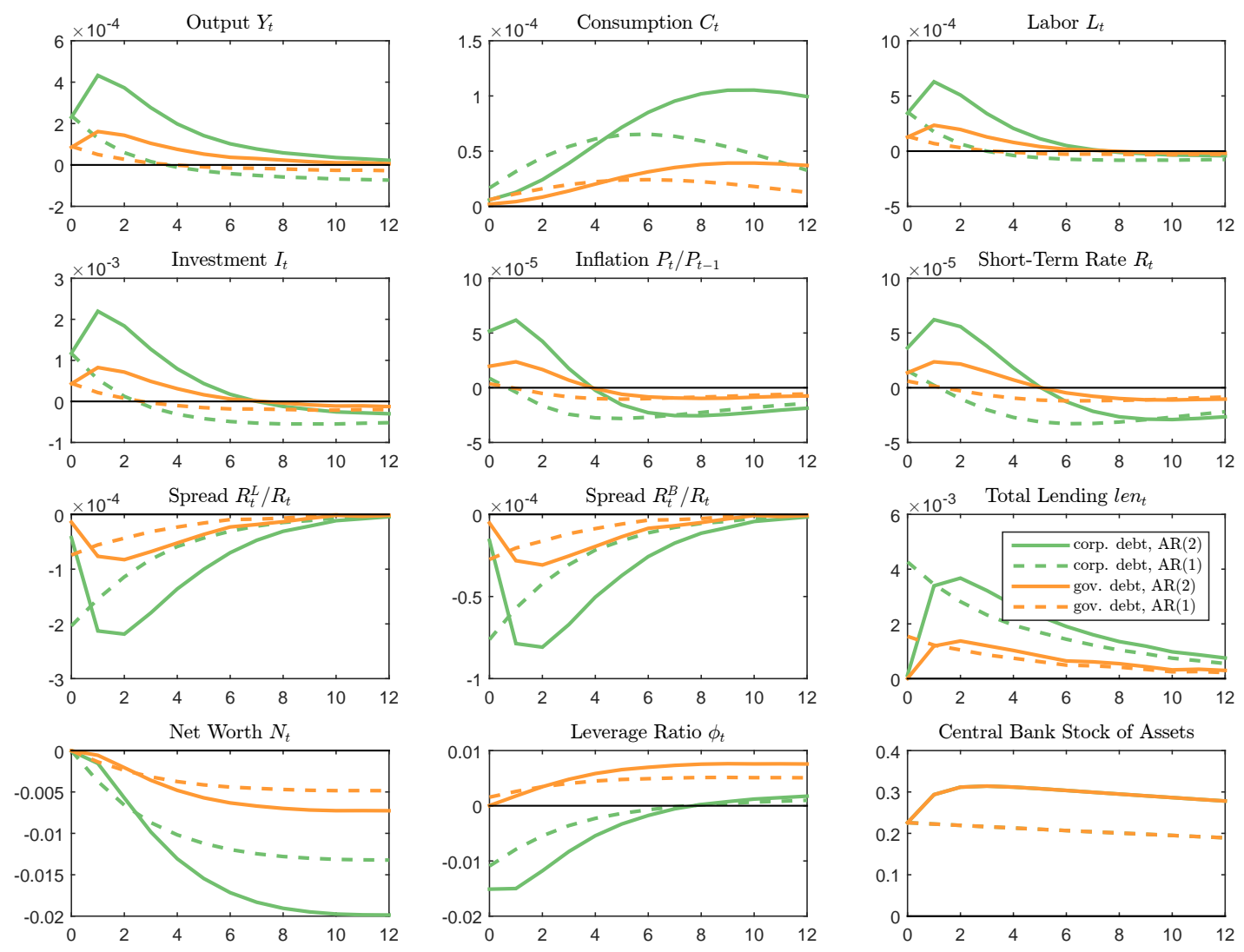

Note: The stock of assets held by the central bank follows either an $\mathrm{AR}(1)$ or $\mathrm{AR}(2)$ process. For the $\operatorname{AR}(1)$ process we set the coefficient of the first lag equal to 0.985 while for the $\operatorname{AR}(2)$ process we set the coefficients of the first lag equal to 1.3 and of the second lag equal to -0.31 . Thus, the largest root of both processes is 0.985 . The impulse responses are computed after taking a second order approximation to the equilibrium conditions of the model. 
However, this effect is short-lived, and turns negative three quarters after the initial shock. The key to understand this result is that by engaging in UMP policies, the central bank worsens the balance sheet position of financial intermediaries. Hence, when the initial UMP impulse is scaled down, banks' reduced net worth does not allow to provide the necessary credit to sustain a higher level of activity, and an investment contraction follows. Because of the reduction in spreads, and the fact that wages are sticky, inflation barely increases on impact and starts declining thereafter. However, the quantitative effect is small.

Using an $\mathrm{AR}(2)$ process fits better the implementation of UMP policies by major central banks, when an announcement of future purchases of securities was generally made, and implemented over the following quarters (see Chen et al., 2012 and Gertler and Karadi, 2013). In this case, the expansionary effects of UMP are long-lasting leading also to an increase in inflation. On the one hand, the decline in net worth is stronger due to the pronounced fall in spreads so that the incentive constraint (10) tightens more compared with the $\mathrm{AR}(1)$ process. On the other hand, the persistence of the UMP shock lowers spreads for a longer period of time, thereby improving refinancing conditions. Given the forward looking behavior of intermediate goods producers, the increase in investment spending is higher, which leads to a persistent, hump-shaped increase in output and employment.

This section has shown the effects of UMP policies when they are considered to be exogenous. From a welfare point of view, simply including additional exogenous shocks to the model would simply reduce welfare. In practice, during the crisis, UMP was deployed because it was reacting to adverse financial conditions. In the following section, we study the optimality of UMP rules that explicitly react to credit spreads.

\section{Welfare Analysis}

In this section, we quantify the benefits of deploying UMP as a standard monetary policy measure with a rule. The main benefit of including an additional policy instrument is to provide an additional tool for macroeconomic stabilization. Gertler and Karadi (2011) discuss the main cost of implementing UMP via lending to the private sector, which is that the central bank is more inefficient than the private financial sector in intermediating credit. Otherwise, given the structure of the model, it would be optimal for the central bank to 
replace commercial banks because it is not subject to an agency problem and is not leverage constrained. Since it is difficult to measure in the data how inefficient the central bank is compared to the private sector in intermediating credit, our results provide an estimate of how large those costs should be for UMP policies not to be worth pursuing. In addition, when UMP policies are implemented through purchases of government bonds, it is not clear that the central bank incurs any additional inefficiency cost of purchasing these bonds compared to having the banking sector buy them. Therefore, our estimates also provide an upper bound of how large the costs of intermediating credit should be, for UMP policies implemented via purchases of government bonds be preferrable to direct lending to firms. In this section, we compare the effects of UMP under the estimated Taylor rule, and under more optimal conventional monetary policy rules.

\subsection{Using The Estimated Taylor Rule}

First, we assess the optimality of UMP in the estimated model, with the estimated policy rule. We use as a welfare criterion the utility function of the representative household:

$$
\mathbb{W}_{t}=\xi_{t}^{\mathcal{U}}\left[\log \left(C_{t}-h C_{t-1}\right)-\psi_{t} \frac{L_{t}^{1+\varphi}}{1+\varphi}\right]+\beta E_{t} \mathbb{W}_{t+1}
$$

We take a second order approximation to the equilibrium conditions and to the welfare function. All the parameters of the model are set at their calibrated or estimated values (as in Tables 1 to 3 ). Lending intermediated by the central bank is given by the following rule:

$$
l e n_{t}^{c b}=\rho_{\Psi} l e n_{t-1}^{c b}+\gamma_{\Psi}\left(R_{t}^{L} / R_{t}-R^{L} / R\right)
$$

with $R^{L} / R$ being the non-stochastic steady state spread. We also experiment with a rule that reacts to the spread on new lending rates (i.e. to $\bar{R}_{t}^{L} / R_{t}-R^{L} / R$ ) rather than average rates. Central bank government bond purchases are given by the following rule:

$$
B_{t}^{c b}=\rho_{\Psi} B_{t-1}^{c b}+\gamma_{\Psi}\left(R_{t}^{L} / R_{t}-R^{L} / R\right)
$$


We also experiment with a rule that reacts to the spread on new lending rates rather than average rates, as well as rules that react to the spread between government bond rates and short-term rates (both average and new). For each UMP rule, we optimize welfare over the coefficients $\rho_{\Psi}$ and $\gamma_{\Psi}$ taking as given the equilibrium conditions of the model. We discuss in the following section why we do not include a second lag in the policy reaction function.

\subsubsection{Optimal Coefficients}

In Table 6, we report the optimal coefficients, the value of the welfare function up to second order, and the difference (in stead-state consumption equivalence terms) from the estimated model (with an estimated Taylor rule and no UMP in place). All policies deliver quantitatively very similar results in terms of welfare. The highest welfare is achieved when the central bank either buys corporate or government bonds to target the average spread on private sector securities. While the coefficient on the responses varies, all these policies entail very large responses to spreads, which in practice it implies that spreads are flattened out. ${ }^{11}$ In addition, we can see that using corporate or government bonds to achieve the results does not make a difference. The choice of implementing UMP with corporate or government bonds would make a difference if the $\Delta_{t}$ shock was very volatile. But, in our estimation, which reflects the behavior of spreads in normal times, it is not. The only case where UMP policies are not desirable is when the central bank buys government bonds to affect the spread on new government debt. It is worth emphasizing again that if providing credit to the private sector entails some inefficiency cost, then a policy that implements purchases of government debt targeting the average lending spread would be the preferred policy. It is interesting to note that when UMP is endogenous, the degree of optimal persistence is high, but never close to a unit root behavior. Hence, we do not study the role of further lags in the UMP reaction function.

Next, we zoom in and examine whether UMP policies are desirable when only a subset of shocks is included. For the purpose of this exercise, we group shocks as follows:

\footnotetext{
${ }^{11}$ In the deterministic steady-state, the value of $l e n_{t}^{c b}$ or $B_{t}^{c b}$ is always zero. However, the mean of the second order approximation does not have to be zero, as it may incorporate risk-correction effects. The optimization procedure includes a large penalty when the mean of the variables $l e n_{t}^{c b}$ or $B_{t}^{c b}$ (as percent of GDP) falls outside the range $[0,50]$. We think that this restriction makes sense to avoid the fact that the central bank short-sells securities or accumulates a very large stock of securities. This is why a policy of "strict spread targeting" is not optimal in Table 6.
} 
Table 6: Optimal UMP Policy

\begin{tabular}{lcccc}
\hline Policy & $\rho_{\Psi}$ & $\gamma_{\Psi}$ & $\mathbb{W}_{t}$ & C.E. (in \%) \\
Corp., $\bar{R}_{t}^{L}-R_{t}$ & 0.972 & 3142.9 & -577.72 & 1.41 \\
Corp., $R_{t}^{L}-R_{t}$ & 0.636 & 37992.7 & -577.56 & 1.45 \\
Gov., $\bar{R}_{t}^{L}-R_{t}$ & 0.786 & 56688.6 & -577.8 & 1.4 \\
Gov., $R_{t}^{L}-R_{t}$ & 0.767 & 65934.6 & -577.56 & 1.45 \\
Gov., $\bar{R}_{t}^{B}-R_{t}$ & 0 & 0 & -583.6 & 0 \\
Gov., $R_{t}^{B}-R_{t}$ & 0.953 & 37985.4 & -577.66 & 1.43 \\
\hline
\end{tabular}

- Supply shocks. This group includes: (i) permanent TFP shocks, (ii) transitory TFP shocks, (iii) investment-specific technology shocks, (iv) labor supply shocks, and (v) price and (vi) wage mark-up shocks.

- Demand shocks. This group includes: (i) the intertemporal preference consumption shock, (ii) the government spending shock, and (iii) the monetary shock.

- Financial shocks. This group includes: (i) the bank capital (net worth) shock, (ii) the fraction of corporate securities that can be diverted by the banker, (iii) the fraction of government securities that can be diverted by the banker, and (iv) the government debt supply shock.

We could compute the optimal response to each particular shock, but we think that this grouping makes sense because it separates "conventional business cycle" supply and demand shocks, from financial shocks. Using this grouping, UMP policies are most relevant when financial shocks hit the economy (Table 7). In fact, most of the welfare gains come from responding optimally to this group of shocks, with a gain of 1.34 percent of steady-state consumption. When only financial shocks are present, the optimal UMP policy is conducted by government bonds affecting the average spread on corporate loans, and interestingly, it is a highly intertial policy, with a value of 0.971 for the inertia coefficient $\rho_{\Psi}$. Under demand or supply shocks, UMP brings about very small welfare gains (0.35 and 0.07 of lifetime consumption). Interestingly, under these conventional business cycle shocks, the best policy is to use government bonds to target the spread on new government rates (a policy that is not deployed at all when we consider all shocks).

Hence, UMP is mostly useful when the economy is hit by financial shocks, but it is not when standard business cycle shocks drive fluctuations. This result echoes the finding of 
Table 7: Optimal UMP Policy, Conditional

\begin{tabular}{ccccc}
\hline \multicolumn{5}{c}{ Demand shocks } \\
\hline Policy & $\rho_{\Psi}$ & $\gamma_{\Psi}$ & $\mathbb{W}_{t}$ & C.E. (in \%) \\
Corp., $\bar{R}_{t}^{L}-R_{t}$ & 0.99 & 26352.9 & -575.96 & .13 \\
Corp., $R_{t}^{L}-R_{t}$ & 0.58 & 1000000 & -576.16 & 0.07 \\
Gov., $\bar{R}_{t}^{L}-R_{t}$ & 0.99 & 7174.87 & -575.96 & .13 \\
Gov., $R_{t}^{L}-R_{t}$ & 0.58 & 1000000 & -576.16 & 0.07 \\
Gov., $\bar{R}_{t}^{B}-R_{t}$ & 0.05 & 14067.2 & -575.05 & 0.35 \\
Gov., $R_{t}^{B}-R_{t}$ & 0.84 & 1000000 & -576.16 & 0.07 \\
\hline \multicolumn{5}{c}{ Supply Shocks } \\
\hline Policy & $\rho_{\Psi}$ & $\gamma_{\Psi}$ & $\mathbb{W}_{t}$ & C.E. (in $\%)$ \\
Corp., $\bar{R}_{t}^{L}-R_{t}$ & 0.05 & 0 & -577.41 & 0 \\
Corp., $R_{t}^{L}-R_{t}$ & 0.87 & 1000000 & -577.21 & 0.05 \\
Gov., $\bar{R}_{t}^{L}-R_{t}$ & 0 & 0 & -577.41 & 0 \\
Gov., $R_{t}^{L}-R_{t}$ & 0.87 & 1000000 & -577.21 & 0.05 \\
Gov., $\bar{R}_{t}^{B}-R_{t}$ & 0.11 & 1136.9 & -577.12 & 0.07 \\
Gov., $R_{t}^{B}-R_{t}$ & 0.99 & 1000000 & -577.21 & 0.05 \\
\hline \multicolumn{5}{c}{ Financial Shocks } \\
\hline Policy & $\rho_{\Psi}$ & $\gamma_{\Psi}$ & $\mathbb{W}_{t}$ & C.E. \\
Corp., $\bar{R}_{t}^{L}-R_{t}$ & 0.911 & 9236.6 & -575.76 & 1.33 \\
Corp., $R_{t}^{L}-R_{t}$ & 0.806 & 20417.1 & -575.76 & 1.33 \\
Gov., $\bar{R}_{t}^{L}-R_{t}$ & 0.801 & 54346.5 & -575.76 & 1.33 \\
Gov., $R_{t}^{L}-R_{t}$ & 0.971 & 9292.1 & -575.74 & 1.34 \\
Gov., $\bar{R}_{t}^{B}-R_{t}$ & 0 & 64317.3 & -576.23 & 1.22 \\
Gov., $R_{t}^{B}-R_{t}$ & 0.955 & 36800.4 & -575.81 & 1.32 \\
\hline \multicolumn{5}{c}{}
\end{tabular}


the literature of the usefulness of QE in a financial crisis and when the economy hits the ZLB. Here we have shown that the same applies away from the ZLB and smaller shocks. We have shown that when the sources of business cycles are not financial, then there is less need for making UMP part of the toolkit. In particular, it is worth emphasizing again that we have not quantified the possible costs of QE. Gertler and Karadi (2011) assume that the central bank is less efficient than commercial banks intermediating credit, and thus there is an efficiency cost when the central bank directly lends to the private sector. The benefits of UMP should be weighted against these costs. We have not included this costs in the model because there is no evidence of how large they might be. And, in the case of QE policies, it is not clear that purchases of government bonds by the central bank are performed less efficiently than by private banks. Perhaps, the benefits of QE policies should be compared to the political costs that they entail, but again, it is difficult to quantify these costs.

\subsubsection{Impulse Response Analysis}

Here we discuss impulse responses to financial shocks as well as the effects of more standard supply and demand shocks. We examine the response under the estimated model, and under the model where UMP is conducted by lending to firms, and reacting to the average lending-deposit spread (the optimal UMP in Table 6).

Figure 2 presents the impulse response to an adverse bank capital or net worth shock. In the estimated model, the shock reduces banks' net worth, and thus leads to to a decline in lending to the private sector, and an increase of spreads for both the corporate and the government sector. As a result, investment and employment decrease, and so does private consumption and real GDP. The response of inflation is muted because its two main components move in different directions: lending rates increase, but real wages (not shown) fall. After falling on impact, inflation therefore increases only by a small amount. Monetary policy basically follows the behavior of inflation through the Taylor rule. The use of UMP completely offsets this shock. In this case, because the shock is contractionary, the central bank lends to firms directly. As a result, aggregate lending does not fall and the spreads do not move. A similar result is obtained by Carlstrom et al. (2016) in a model with financial frictions and real and financial shocks like the one we presented here.

Figure 3 presents the impulse response to an increase in government debt. This increase 
Figure 2: Impulse Response to a Net Worth Shock
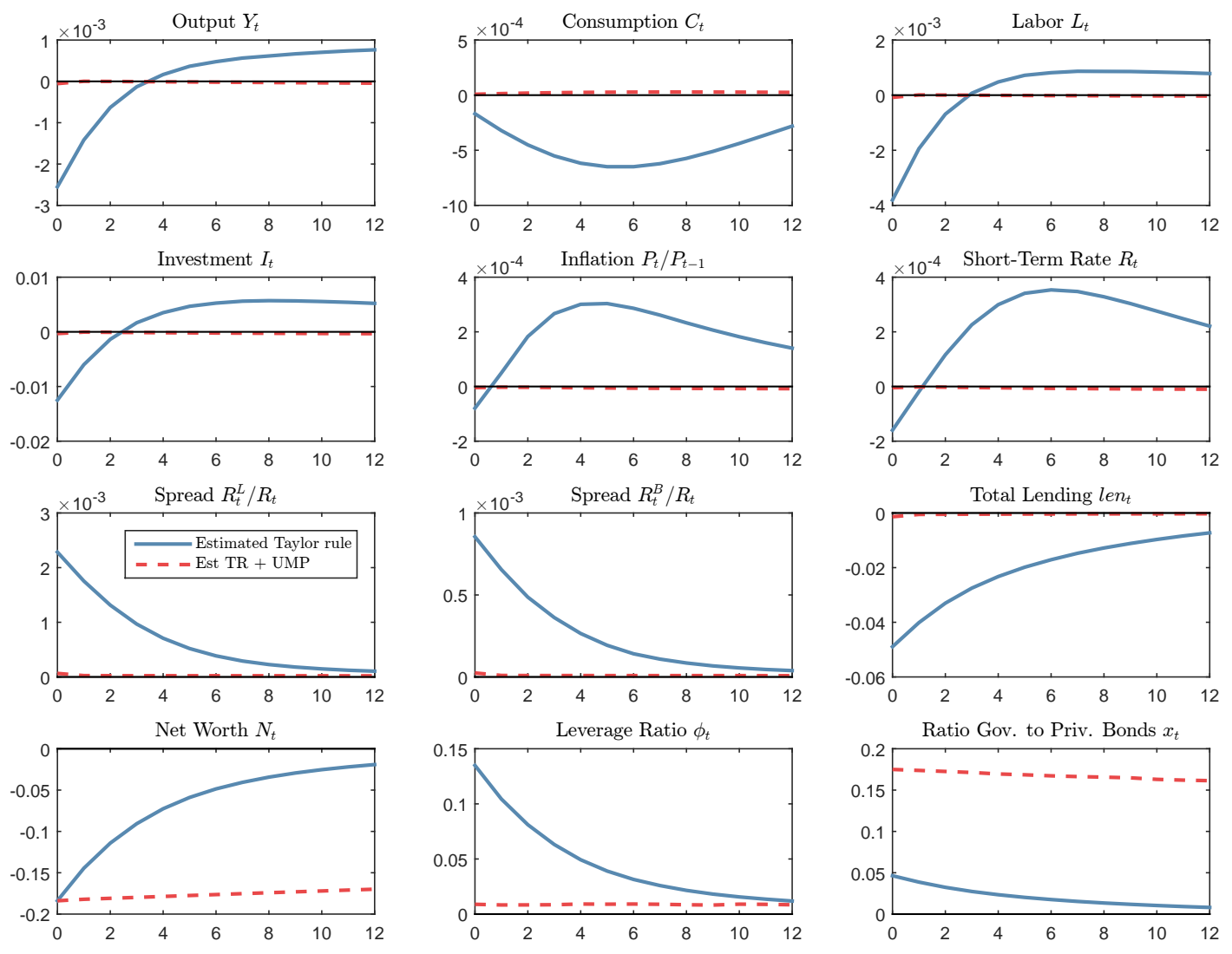

Note: The impulse responses are computed after taking a second order approximation to the equilibrium conditions of the model. 
Figure 3: Impulse Response to a Government Debt Supply Shock
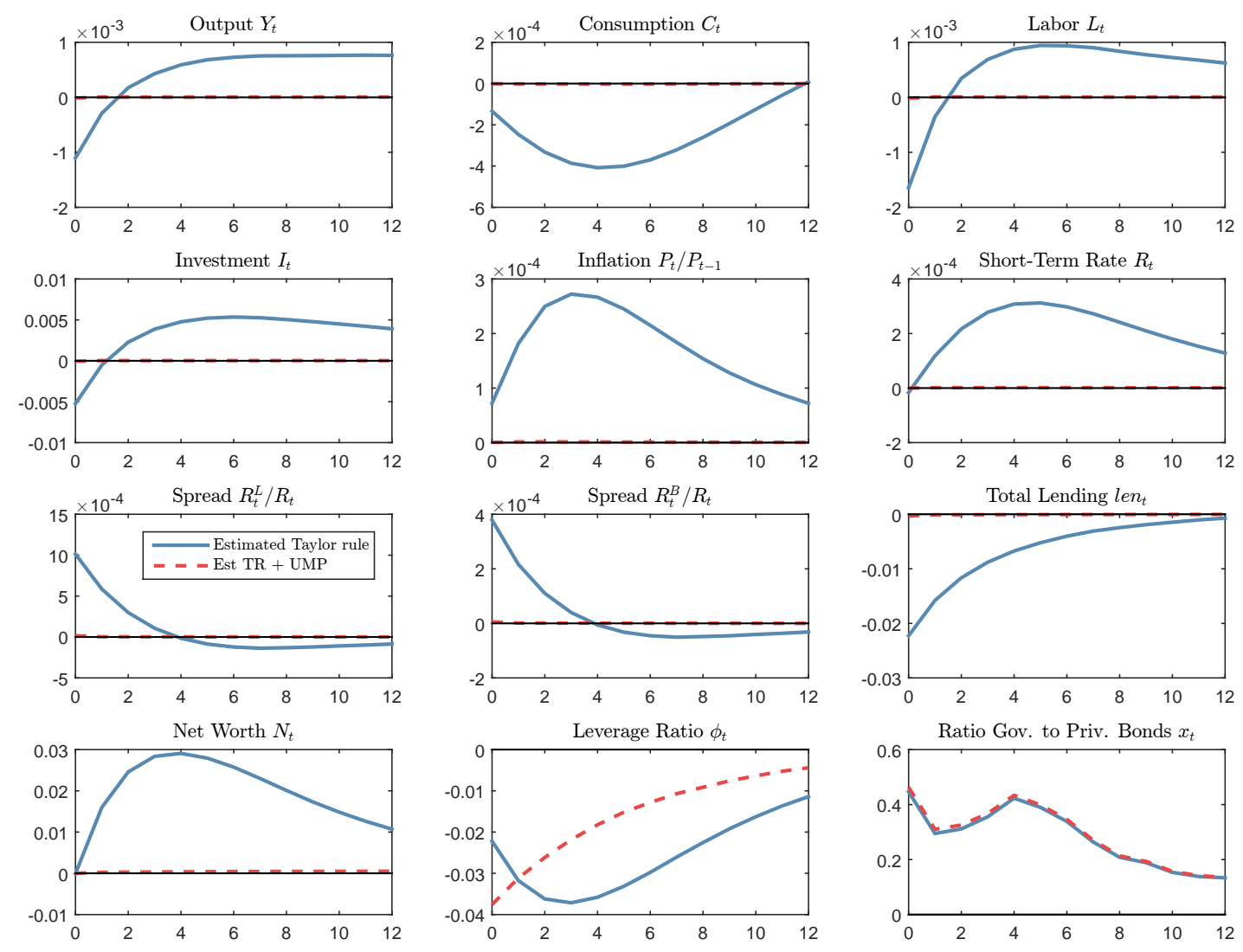

Note: The impulse responses are computed after taking a second order approximation to the equilibrium conditions of the model.

could be motivated by a reduction in tax revenue while keeping government spending constant. An increase in government debt that needs to be financed by the banking sector leads to an initial crowding out: spreads on both government and corporate debt increase, reducing lending, investment, labor demand, and hence GDP and consumption. Interestingly, the balance sheet position of banks improves because of the increased lending markings. However, the negative effects of this shock are short-lived, because this shock is not very persistent (the $\mathrm{AR}(1)$ coefficient is estimated to be 0.833$)$. This means that spreads return quite rapidly to their steady-state values, and investment, labor demand and output rebound. UMP policies are extremely effective at insulating the real economy from this shock.

Having established that UMP is useful when the economy is hit by financial shocks, we now study what happens when the economy is hit by more standard supply and demand 
shocks. For this purpose, we present the impulse responses to a temporary TFP shock, an investment-specific technology shock, a consumption preference shock, and a government spending shock. ${ }^{12}$ The effects of a temporary TFP shock are fairly standard and similar to a model without financial frictions (see, for instance, Smets and Wouters, 2007). GDP, consumption and investment increase, while hours worked and inflation decline (Figure 4). The central bank cuts interest rates as a result. In the financial sector, lending increases immediately because of increased credit demand, but it takes a while for banks to accumulate more net worth: the leverage ratio increases and so does the lending-deposit spread. In this sense, the financial friction dampens the initial effect of the shock because of the lack of resources to invest. Deploying UMP removes the financial friction and allows the economy to reap the benefits of higher productivity. In this case, the central bank is able to stabilize the spread completely, generating an even larger effect on investment and GDP. The effect on consumption and labor is much smaller, which explains why, in terms of welfare, the effect of UMP under supply shocks is small.

The effects of an investment-specific technology shock are also fairly standard, as in Justiniano et al. (2011) (Figure 5). Investment, GDP, consumption and labor increase. Unlike the case of the TFP shock, inflation also increases because the technology improvement is in the capital goods sector rather than the consumption goods sector, so the marginal cost of production in the latter actually increases. The inclusion of the financial sector and financial frictions has the following effect: in this case, total lending declines because the price of capital goods is cheaper: the amount that firms need to borrow, when expressed in nominal or in consumption goods, actually declines. This smaller demand for credit translates into lower spreads. Note, however, that the effect on spreads is quantitatively very small. As a result, when UMP policies aim at stabilizing spreads, the impulse responses with respect to the main macro variables do not really change.

The effects of a consumption preference shock are also fairly standard (Figure 6). They lead to a consumption boom and higher inflation, but lower investment and GDP. Financial accelerator effects are very small, and hence there is not much that the central bank can do by using UMP. When UMP is deployed, it does not really affect the behavior of main

\footnotetext{
${ }^{12}$ The results are representative to what happens under any other supply or demand shock. To save space, we omit the analysis for all other supply and demand shocks in the model, but they are available upon request.
} 
Figure 4: Impulse Response to a Temporary TFP Shock
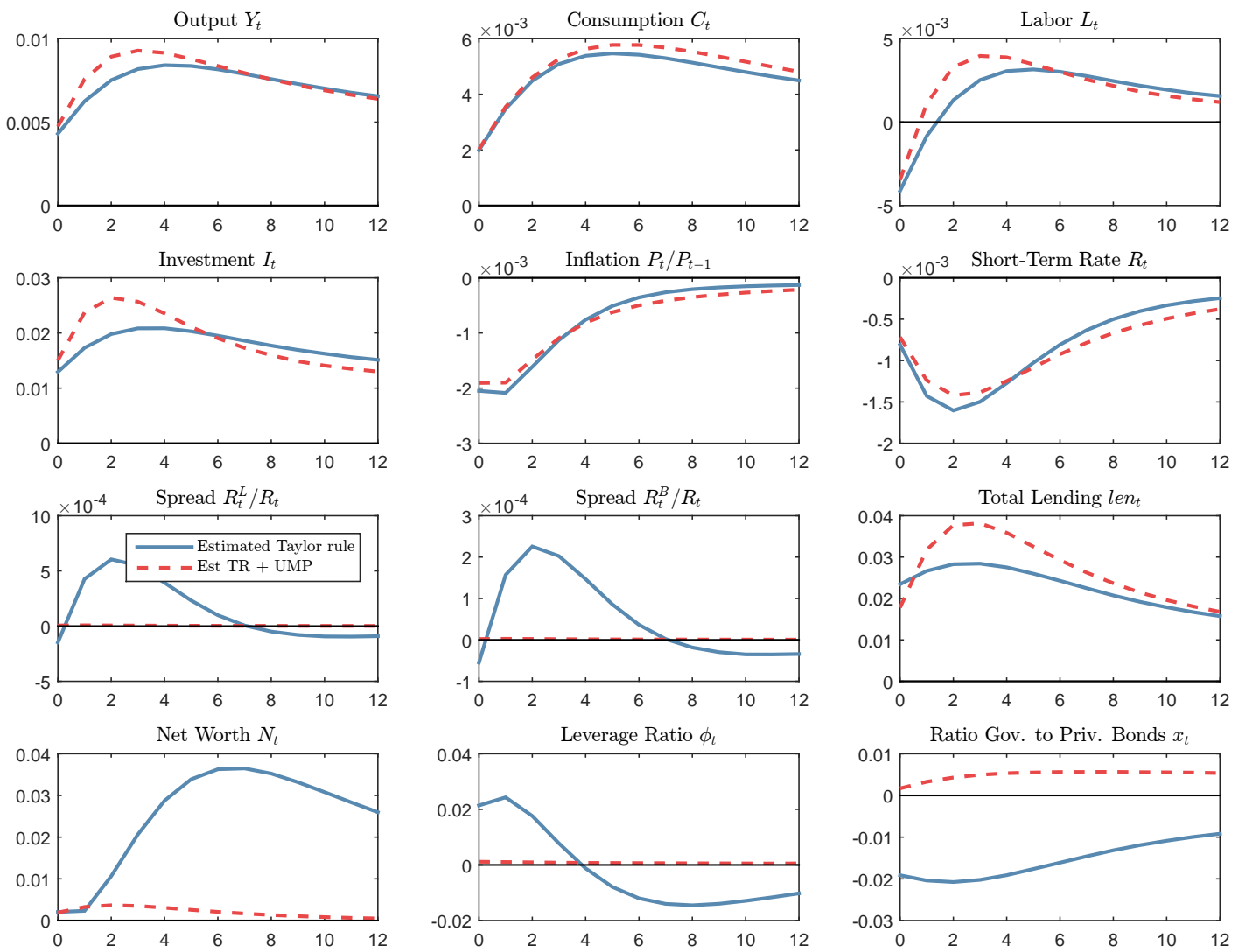

Note: The impulse responses are computed after taking a second order approximation to the equilibrium conditions of the model. 
Figure 5: Impulse Response to an Investment-Specific Technology Shock
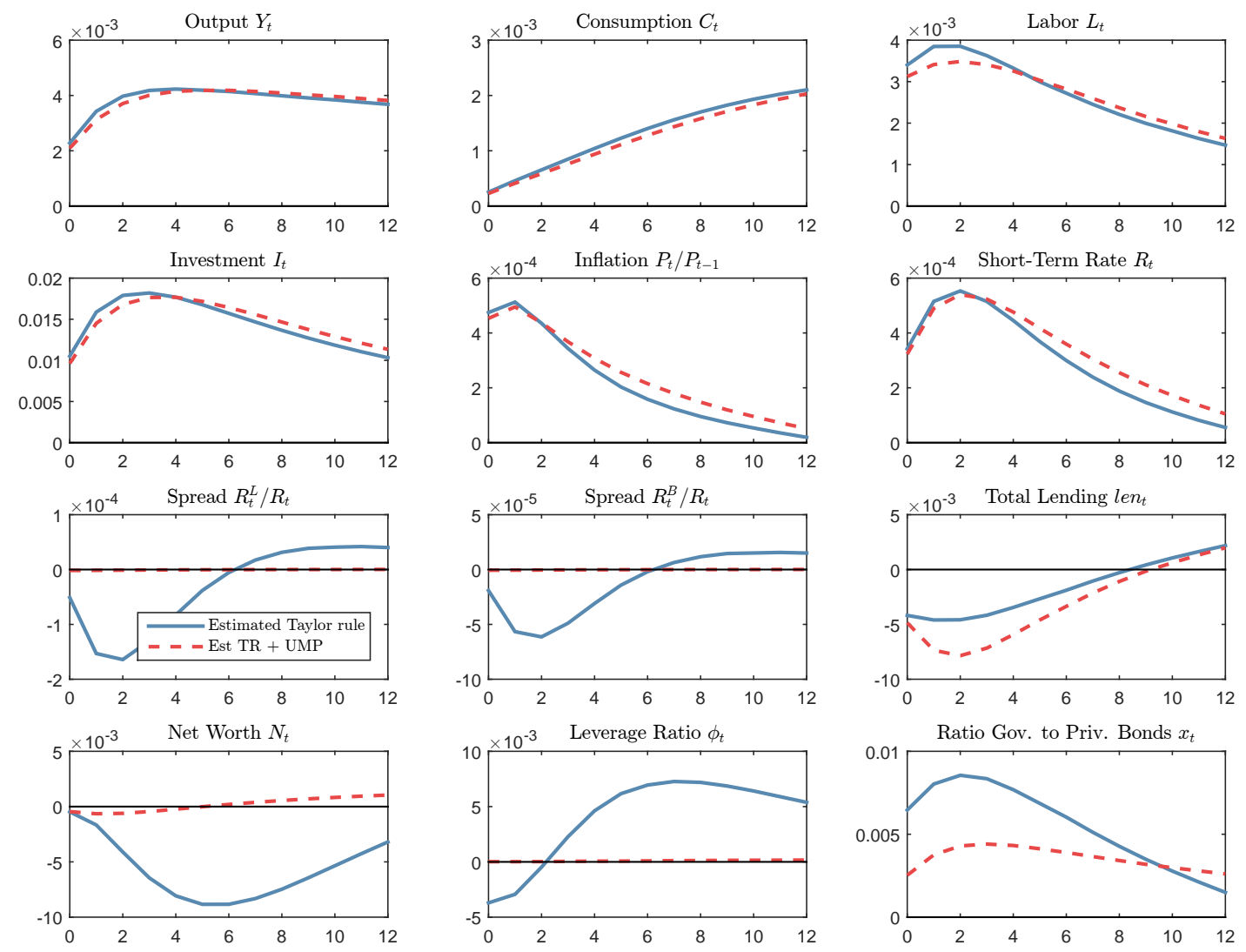

NotE: The impulse responses are computed after taking a second order approximation to the equilibrium conditions of the model. 
Figure 6: Impulse Response to a Consumption Preference Shock
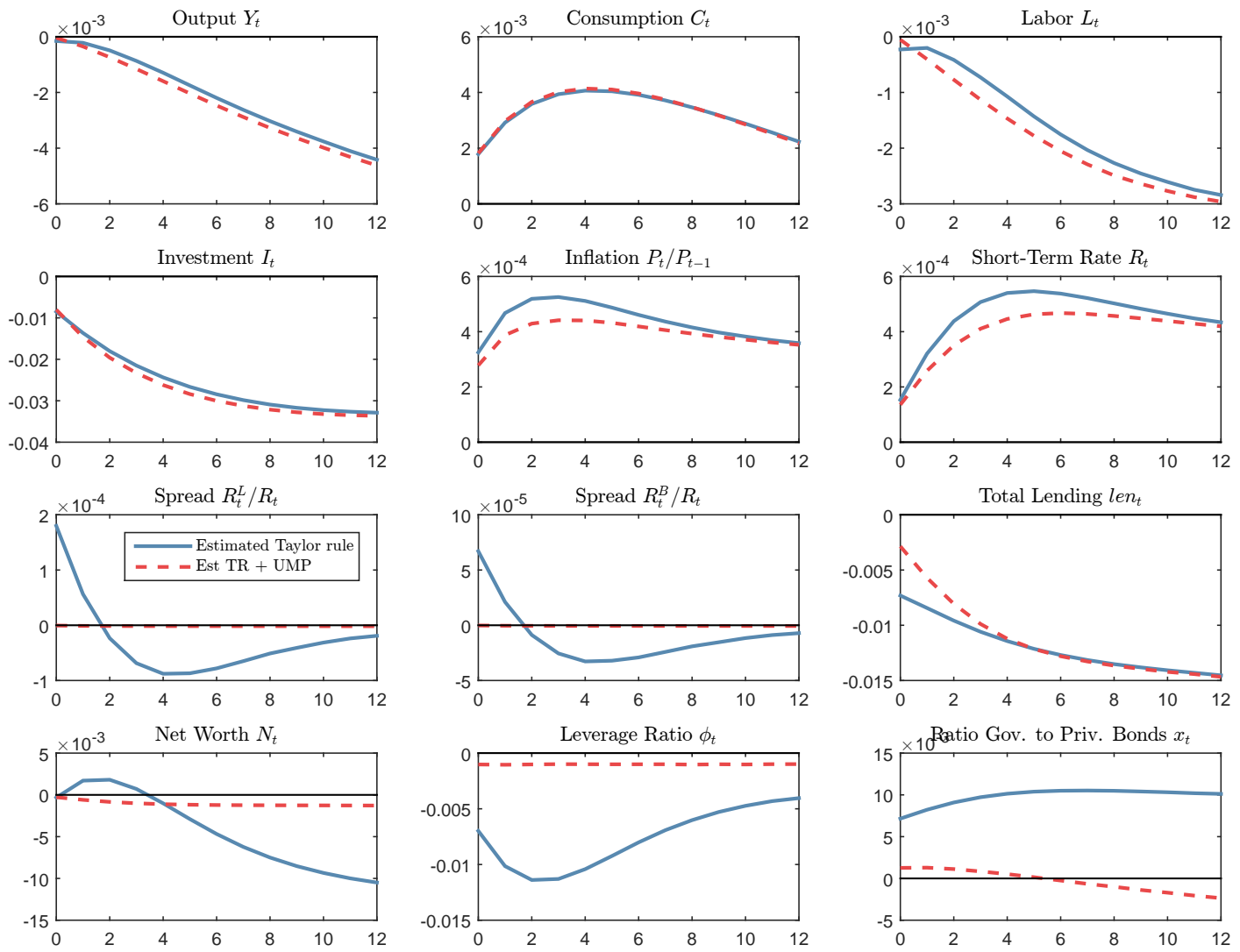

Note: The impulse responses are computed after taking a second order approximation to the equilibrium conditions of the model.

variables, including consumption and hours, in a significant way.

Finally, we present the effects of a government spending shock (Figure 7). This shock does not increase government debt because lump-sum taxes adjust to keep debt constant. The effects of this shock are quite standard, and the introduction of financial frictions does not alter its effects. Specifically, the increase in government spending increases GDP and labor demand, but it crowds out consumption and investment. Inflation and short-term interest rates increase. The decline in investment leads to a reduction in lending, which in turn translates into lower spreads, and reduces banks' net worth. When UMP is deployed, the effect is mostly felt on financial variables: spreads and bank capital are almost fully stabilized. However, the reaction of macroeconomic variables, and in particular the reaction of consumption and labor are extremely similar, which explains the small effect of UMP on 
Figure 7: Impulse Response to a Government Consumption Shock
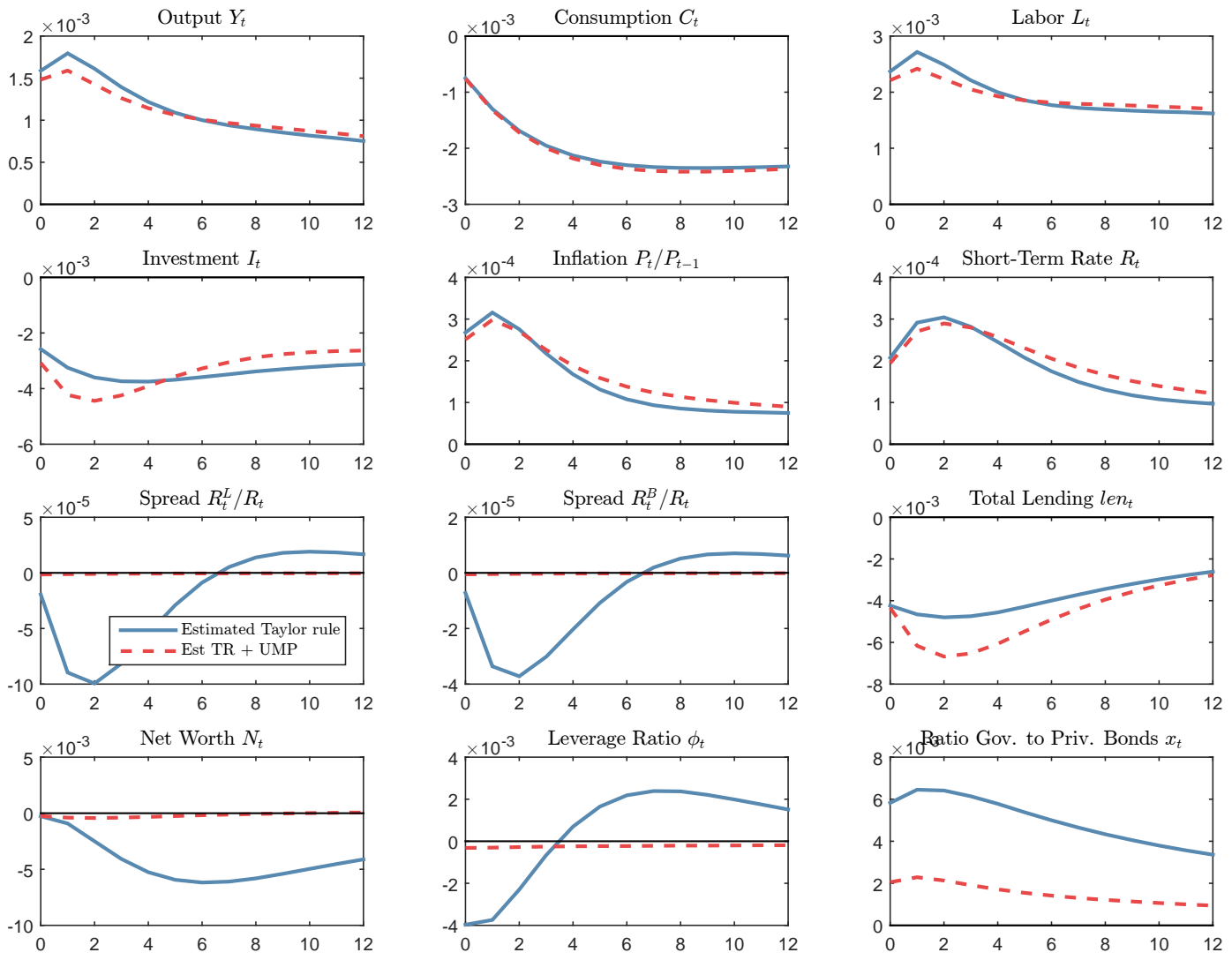

Note: The impulse responses are computed after taking a second order approximation to the equilibrium conditions of the model.

welfare under demand shocks.

\subsection{Using Alternative Monetary Policy Rules}

We have analyzed the role of UMP when monetary policy is conducted according to the estimated Taylor rule. Next, as a robustness exercise, we look at what happens when monetary policy follows two types of more optimal rules: (i) a strict inflation targeting rule, and (ii) a policy aiming at targeting price and wage inflation. This way we can evaluate if there is a role for UMP when conventional monetary policy is conducted in a more optimal way. The results are presented in Tables 8 and 9 .

Under strict inflation targeting, the results are virtually unchanged: UMP matters and the welfare gains are exactly the same as under the estimated rule: 1.45 percent of lifetime 
Table 8: Optimal UMP Policy, Strict Inflation Targeting

\begin{tabular}{llcccc}
\hline Shocks & Policy & $\rho_{\Psi}$ & $\gamma_{\Psi}$ & $\mathbb{W}_{t}$ & C.E. (in \%) \\
\hline All & Corp., $\bar{R}_{t}^{L}-R_{t}$ & 0.14 & 9.62 & -553.83 & 1.45 \\
Demand & Corp., $\bar{R}_{t}^{L}-R_{t}$ & 0.11 & 11985.56 & -576.96 & 0.11 \\
Supply & All & 0 & 0 & -553.67 & 0 \\
Financial & Gov., $\bar{R}_{t}^{L}-R_{t}$ & 0.97 & 9163.7 & -575.74 & 1.12 \\
\hline
\end{tabular}

Table 9: Optimal UMP Policy, Price and Wage Inflation Targeting

\begin{tabular}{llcccc}
\hline Shocks & Policy & $\rho_{\Psi}$ & $\gamma_{\Psi}$ & $\mathbb{W}_{t}$ & C.E. (in \%) \\
\hline All & All & 0 & 0 & -554.49 & 0 \\
Demand & Corp., $\bar{R}_{t}^{L}-R_{t}$ & 0.03 & 19128.0 & -577.02 & 0.09 \\
Supply & All & 0 & 0 & -553.67 & 0 \\
Financial & Gov., $\bar{R}_{t}^{B}-R_{t}$ & 0 & 1.39 & -580.25 & 0.16 \\
\hline
\end{tabular}

consumption. These gains are most important under financial shocks. However, under a strict inflation targeting two new results appear. First, the optimal UMP under supply shocks is to not use it. Under the six possible alternatives, the coefficients are always zero. Second, with demand shocks, the welfare gains are higher than under the estimated rule.

As a final robustness check, we study what happens under an optimized Taylor rule that targets both price and wage inflation. Since the model has price and wage stickiness, a Taylor rule that targets both price and wage inflation is optimal (see Erceg, Henderson and Levin, 2000). We find that in the estimated model, the optimized Taylor rule takes the form of

$$
\frac{R_{t}}{R}=\left(\frac{R_{t-1}}{R}\right)^{\gamma_{R}}\left(\frac{\pi_{t}}{\pi}\right)^{\gamma_{\Pi}\left(1-\gamma_{R}\right)}\left[\frac{\left(\tilde{W}_{t} / \tilde{W}_{t-1}\right) \exp \left(\Lambda_{t}\right)}{\exp (\Lambda)}\right]^{\gamma_{W}\left(1-\gamma_{R}\right)} \exp \left(\epsilon_{m, t}\right)
$$

where $\gamma_{R}=0.00, \gamma_{\Pi}=23403.33$, and $\gamma_{W}=7784.26 .{ }^{13}$ In this case, the welfare improvements from using unconventional monetary policies become even smaller. In fact, when all shocks are taken into account, the optimal unconventional policy is to not interviene. However, when the optimality of UMP is studied under a subset of shocks, then it is still optimal to deploy it under demand or financial shocks, but the effects are substantially lower than under the estimated Taylor rule or the strict inflation targeting rule.

To conclude, in this section we have shown that if monetary policy is conducted under a standard, estimated Taylor rule, then including a second policy instrument in the form of

\footnotetext{
${ }^{13}$ We also studied optimized Taylor rules that include output growth, but found that the optimal response to that variable is 0 .
} 
unconventional monetary policy can have sizable welfare effects, specially when the economy is hit by financial shocks. This result still holds when the central bank follows a strict inflation targeting rule with conventional monetary policy. Under a rule that targets price and wage inflation, the welfare effects are much smaller.

\section{Conclusions}

In this paper, we have examined if the Fed should keep UMP policies in place once interest rates normalize, in a model with a banking sector that engages in maturity transformation and which is estimated using nonlinear techniques. We have found that the answer is yes: there are welfare benefits from using UMP to address the effects of financial frictions and especially financial shocks, to the economy. However, we have also found that under more traditional supply and demand shocks, the benefits of using UMP are much smaller. In this paper, we have made no attempt to quantify the possible costs of introducing UMP, such as less efficient intermediation and monitoring by the central bank. It is quite likely that UMP should not be used under supply shocks, given its small benefits in this case. We have also found that providing credit to the private sector or purchasing government bonds has very similar effects to the economy. But, if purchases of government bonds entail lower (or no costs) compared to direct lending to the private sector, then the former policy might be preferable to the latter. 


\section{References}

An, S. and Schorfheide, F. (2007). Bayesian Analysis of DSGE Models. Econometric Reviews, 26 (2-4), 113-172.

Andreasen, M. M., Ferman, M. and Zabczyk, P. (2013). The Business Cycle Implications of Banks Maturity Transformation. Review of Economic Dynamics, 16 (4), 581 600.

-, Fernández-Villaverde, J. and Rubio-Ramírez, J. F. (2016). The Pruned StateSpace System for Non-Linear DSGE Models: Theory and Empirical Applications. Mimeo, University of Pennsylvania.

Calvo, G. (1983). Staggered Prices in a Utility-Maximizing Framework. Journal of Monetary Economics, 12 (3), 383-398.

Carlstrom, C. T., Fuerst, T. S. and Paustian, M. (2016). Targeting Long Rates in a Model with Segmented Markets. American Economic Journa: Macroeconomicsl, forthcoming.

Chen, H., Cúrdia, V. and Ferrero, A. (2012). The Macroeconomic Effects of Largescale Asset Purchase Programmes. The Economic Journal, 122 (564), F289-F315.

Christiano, L. J. and Eichenbaum, M. (1992). Current Real-Business-Cycle Theories and Aggregate Labor-Market Fluctuations. American Economic Review, 82 (3), 430-50.

-, Motto, R. and Rostagno, M. (2014). Risk Shocks. American Economic Review, $104(1), 27-65$.

Cúrdia, V. and Woodford, M. (2011). The Central-Bank Balance Sheet as an Instrument of Monetary Policy. Journal of Monetary Economics, 58 (1), 54 - 79.

Del Negro, M., Eggertsson, G., Ferrero, A. and Kiyotaki, N. (2016). The Great Escape? A Quantitative Evaluation of the Fed's Liquidity Facilities. NBER Working Papers 22259, National Bureau of Economic Research, Inc. 
Eggertsson, G. B. and Woodford, M. (2003). The Zero Bound on Interest Rates and Optimal Monetary Policy. Brookings Papers on Economic Activity, 34 (1), 139-235.

Ellison, M. and Tischbirek, A. (2014). Unconventional Government Debt Purchases as a Supplement to Conventional Monetary Policy. Journal of Economic Dynamics and Control, 43, 199 - 217, the Role of Financial Intermediaries in Monetary Policy Transmission.

Erceg, C. J., Henderson, D. W. and Levin, A. T. (2000). Optimal Monetary Policy with Staggered Wage and Price Contracts. Journal of Monetary Economics, 46 (2), 281 -313 .

FAmA, E. F. (1970). Efficient Capital Markets: A Review of Theory and Empirical Work. The Journal of Finance, 25 (2), 383-417.

Fernández-Villaverde, J. and Rubio-Ramírez, J. F. (2007). Estimating Macroeconomic Models: A Likelihood Approach. Review of Economic Studies, 74 (4), 1059-1087.

Fratzscher, M., Duca, M. L. and Straub, R. (2016). ECB Unconventional Monetary Policy: Market Impact and International Spillovers. IMF Economic Review, 64 (1), 36-74.

Gagnon, J., Raskin, M., Remache, J. and Sack, B. (2011). The Financial Market Effects of the Federal Reserve's Large-Scale Asset Purchases. International Journal of Central Banking, 7 (1), 3-43.

Gertler, M. and Karadi, P. (2011). A Model of Unconventional Monetary Policy. Journal of Monetary Economics, 58 (1), 17 - 34.

— and - (2013). QE 1 vs. 2 vs. 3. . . : A Framework for Analyzing Large-Scale Asset Purchases as a Monetary Policy Tool. International Journal of Central Banking, 9 (1), $5-53$.

— and Kiyotaki, N. (2010). Financial Intermediation and Credit Policy in Business Cycle Analysis. In B. M. Friedman and M. Woodford (eds.), Handbook of Monetary Economics, vol. 3, Elsevier, pp. $547-599$. 
Greenspan, A. (2005). Federal Reserve Board's semiannual Monetary Policy Report to the Congress. Before the Committee on Banking, Housing, and Urban Affairs, U.S. Senate February 16, 2005.

Ivashina, V. and Scharfstein, D. (2010). Bank lending during the financial crisis of 2008. Journal of Financial Economics, 97 (3), 319 - 338.

Justiniano, A., Primiceri, G. and Tambalotti, A. (2011). Investment Shocks and the Relative Price of Investment. Review of Economic Dynamics, 14 (1), 101-121.

—, Primiceri, G. E. and Tambalotti, A. (2013). Is There a Trade-Off between Inflation and Output Stabilization? American Economic Journal: Macroeconomics, 5 (2), 1-31.

Krishnamurthy, A. and Vissing-Jorgensen, A. (2011). The Effects of Quantitative Easing on Interest Rates: Channels and Implications for Policy. Brookings Papers on Economic Activity, 43 (2), 215-287.

Lenza, M., Pill, H. and Reichlin, L. (2010). Monetary Policy in Exceptional Times. The Economic Policy, 25 (4), 295-339.

McGough, B., Rudebusch, G. D. and Williams, J. C. (2005). Using a long-term interest rate as the monetary policy instrument. Journal of Monetary Economics, 52 (5), $855-879$.

Reiter, M., Sveen, T. and Weinke, L. (2013). Lumpy Investment and the Monetary Transmission Mechanism. Journal of Monetary Economics, 60 (7), 821 - 834.

Rotemberg, J. J. (1982). Monopolistic Price Adjustment and Aggregate Output. The Review of Economic Studies, 49 (4), 517-531.

Ruge-Murcia, F. J. (2007). Methods to estimate dynamic stochastic general equilibrium models. Journal of Economic Dynamics and Control, 31 (8), 2599-2636.

Smets, F. and Wouters, R. (2003). An Estimated Dynamic Stochastic General Equilibrium Model of the Euro Area. Journal of the European Economic Association, 1 (5), $1123-1175$. 
— and - (2007). Shocks and Frictions in US Business Cycles: A Bayesian DSGE Approach. American Economic Review, 97 (3), 586-606.

Sveen, T. and Weinke, L. (2007). Lumpy investment, sticky prices, and the monetary transmission mechanism. Journal of Monetary Economics, 54 (Supplement), 23-36.

Thornton, D. L. (2012). Greenspan's Conundrum and the Fed's Ability to Affect LongTerm Yields. Federal Reserve Bank of St. Louis Working Paper Series 2012-036.

Wallace, N. (1981). A Modigliani-Miller Theorem for Open-Market Operations. American Economic Review, 71 (3), 267-274.

Woodford, M. (2001). Fiscal Requirements for Price Stability. Journal of Money, Credit and Banking, 33 (3), 669-728. 